\title{
AUNC
}

Zabytkoznawstwo i Konserwatorstwo XLVII

Toruń 2016

DOI: http://dx.doi.org/10.12775/AUNC_ZiK.2016.001

\section{Mosiądz w starożytności i średniowieczu. Przyczynek do dziejów kultury materialnej}

\section{ALINA TOMASZEWSKA-SZEWCZYK}

Zakład Konserwacji Elementów i Detali Architektonicznych, Wydział Sztuk Pięknych, UMK w Toruniu e-mail: alina.tomaszewska-szewczyk@umk.pl

Keys words: brass, technology, cadmia, cementation, Theophilus Presbyter, auricalcum, aes

Słowa kluczowe: mosiądz, technologia, kadmia, cementacja, Mnich Teofil, auricalcum, aes

\begin{abstract}
Brass in ancient and medieval times

Contribution to the history of material culture

Brass was obtained in present-day India during the early Iron Age. Although zinc was distilled in the mines in Zawar (India) as early as in the $9^{\text {th }} \mathrm{c}$. CE, the method only influenced European brass-smelting in mid-18th c. In ancient Europe, copper zinc alloys were produced by combining copper with calamine (zinc ores): hemimorphite or smithsonite (zinc spar). During the early days of the Roman Empire, cadmia, i.e. zinc oxide found on the walls of furnaces used for smelting ores containing the metal, was also employed for the purpose. The method, called cementation and believed to rely on refining copper, remained the only one practiced in Europe until the end of the 18 th century.

As a sculptural material, brass did not become popular in Europe until the Middle Ages. The Meuse basin, where ancient traditions were continued in the workshops of Dinant, Givet, Liège or Cologne, played a major part in the process, and production developed with the birth of the Frankish Empire. Beside major manufactures, local production also developed; for instance, evidence of brass production in Kruszwica, Poland, dates back to mid-11th c. The main source of data on the production and
\end{abstract}


processing of medieval brass is Diversarum Artium Schedula, a treatise complied by Theophilus Presbyter, which describes two types of alloys: aes (leaded brass) and auricalcum. The properties of these alloys were consciously selected to suit individual purposes.

\begin{abstract}
Abstrakt
Mosiądz otrzymano w Indiach w okresie wczesnej epoki żelaza. W Zawarze (Indie) już w IX w. n.e. opanowano umiejętność destylacji cynku. Technologia ta wywarła wpływ na produkcję mosiądzu w Europie dopiero w I połowie XVIII w., chociaż umiejętnością sporządzania mosiężnych stopów posługiwano się już w starożytności. Otrzymywano je przez stapianie miedzi z rudami cynku - galmanami (smithsonit, hemimorfit), a w wyniku rozwoju technologii w okresie wczesnego cesarstwa także z kadmią, tlenkiem cynku zbieranym w kominach pieców hutniczych w czasie wytapiania rud metali, w skład których wchodził ten metal. Metoda ta była jedynym praktycznie stosowanym sposobem sporządzania mosiądzów do końca XVIII w. Proces uważano za sposób uszlachetniania miedzi i nazywano cementacją.

Jako tworzywo rzeźbiarskie mosiądze upowszechniły się w Europie dopiero w średniowieczu, a kluczową rolę w tym procesie odegrały wyrosłe z tradycji antycznej warsztaty nadmozańskie, między innymi w Dinant, Givet, Liège oraz w Kolonii. Pierwszy duży impuls do rozwoju tej produkcji przyszedł z nastaniem monarchii Franków. W XI wieku w Saksonii zaczął się tworzyć drugi ważny region produkcji mosiądzu i rzemiosła mosiężnego. Obok tak znaczących ośrodków zaczęła się kształtować produkcja na miarę potrzeb lokalnych, na przykład z połowy XI wieku pochodzą ślady wytwarzania wyrobów mosiężnych w Kruszwicy. Źródłem wiedzy na temat technologii i przeróbki mosiądzów w okresie średniowiecza jest traktat Mnicha Teofila „Diversarum Artium Schedula”, gdzie opisane zostały dwa typy stopów: aes (mosiądz ołowiany) oraz auricalcum. Ich właściwości dobierane były w sposób świadomy w zależności od przeznaczenia.
\end{abstract}

Mosiądz nie odegrał tak dużej roli w gospodarce i sztuce antycznej jak brąz, a jeden z jego podstawowych składników - cynk hutniczy - w Europie otrzymywano w procesie metalurgicznym dopiero od połowy XVIII wieku. Natomiast pierwsze wyroby z miedzi, takie jak koraliki, szpile i narzędzia znalezione na Bliskim Wschodzie na stanowisku Çayönü (obecna południowowschodnia Turcja), wytwarzano w neolicie w okresie przedceramicznym, czyli w połowie VII tysiąclecia p.n.e. lub nawet wcześniej ${ }^{1}$. Uważa się, że te przed-

Encyklopedia sztuki starożytnej. Europa. Azja. Afryka. Ameryka (Warszawa: WAiF; Warszawa: PWN, 1998), 136-137. 
mioty wykonano z samorodków poddanych obróbce na zimno². W połowie VI tysiąclecia p.n.e. na terenie obecnego Iraku w kulturach Hassuna i Samarra do produkcji biżuterii i narzędzi wykorzystywano już także miedź wytapianą z rudy ${ }^{3}$. Nieznajomość drugiego składnika stopu mosiężnego w postaci metalicznej nie była jednak przeszkodą w jego sporządzaniu, dlatego kluczowymi zagadnieniami w poznaniu historii technologii mosiądzu są petrologia rud cynkonośnych oraz ich metalurgia.

\section{Petrologia złóż cynkonośnych; galmany i blenda cynkowa}

Cynk rodzimy należy do bardzo rzadkich minerałów, znanych jest tylko kilka jego lokalizacji, natomiast jego związki są rozpowszechnione w skorupie ziemskiej. Rudy cynkowe występują najczęściej z ołowianymi, rzadziej z innymi rudami, m.in. srebra, miedzi, antymonu, arsenu, tworząc złoża polimetaliczne. Dla antycznych, średniowiecznych, a nawet nowożytnych metalurgów największe znaczenie miały złoża zalegające w górnych warstwach litosfery i powstające w rezultacie wietrzenia siarczku cynku wchodzącego w skład blendy cynkowej, zbudowane głównie z węglanowych i krzemianowych minerałów cynku. Ich drobnokrystaliczne, zbite odmiany tworzące mieszaninę mineralną z dolomitem, kalcytem, kwarcem, minerałami ilastymi, a także domieszkami goethytu i galeny, nazywa się galmanami ${ }^{4}$, formy ziarniste, groniaste lub naciekowe - kalaminem, a o doskonałej łupliwości - spatem cynkowym. Dopiero w 1802 roku James Smithson na podstawie badań rud pochodzących z kilku złóż ustalił, że w ich skład wchodzą dwa minerały o zbliżonych cechach fizycznych: smithsonit (fot. 1) i mniej rozpowszechniony hemimorfit (fot. 2) ${ }^{5}$.

2 Michael Roaf, Wielkie kultury świata. Mezopotamia (Warszawa: Świat Książki: Diogenes,1998), 35.

3 Roaf, Wielkie kultury, 47.

4 Barbara Radwanek-Bąk, „Charakterystyka petrograficzna utlenionych rud cynku ze złóż obszarów Bolesławia i Olkusza”, Rocznik Polskiego Towarzystwa Geologicznego 53 (1983) 1-4: 235-236, https://geojournals.pgi.gov.pl/asgp/article/download/12034/10509 (dostęp 19 marca 2016).

5 James Smithson, “A Chemical Analysis of Some Calamines”, Philosophical Transactions of the Royal Society of London 93 (1803): 12-28, http://rstl.royalsocietypublishing.org/content/93/12.full.pdf+html (dostęp 19 marca 2016). 
a
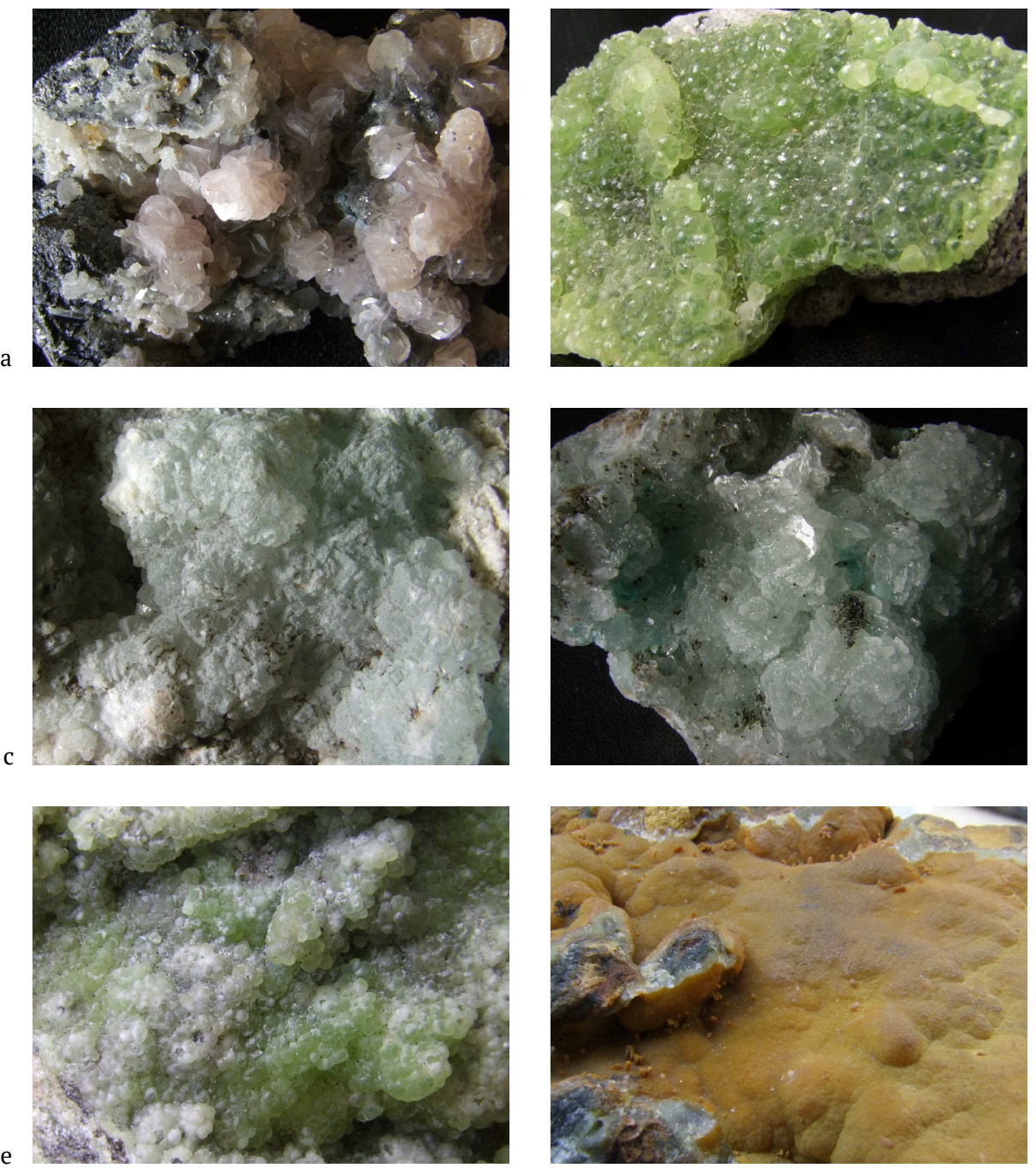

Fot.1. Smithsonit ${ }^{6}\left(\mathrm{ZnCO}_{3}\right)$, gromada węglany, grupa kalcytu:

a -bladoróżowe kryształy o perłowym połysku na galenie, Tsumeb, Namibia,

$\mathrm{b}$-zielone groniaste naskorupienia, Hauden, Gila County, Arizona, USA,

c - białe i delikatnie zabarwione na zielono naskorupienia, Lawrio (Laurion), Grecja,

d -białe i delikatnie zabarwione na błękitno kryształy, Hauden, Gila County, Arizona, USA,

e -żółte naskorupienia groniaste, Hauden, Gila County, Arizona, USA

f - żółtobrunatne naskorupienia, Eschweiler, Stolberg, Aachen, Niemcy

Fot. A. Tomaszewska-Szewczyk (zbiory własne)

6 Użyte w tekście nazwy minerałów, ich systematyka oraz wzory chemiczne zgodnie z: Jan Parafiniuk, Minerały. Systematyczny katalog 2004 (Warszawa: Towarzystwo Geologiczne „Spirifer”, 2005), oraz Jerzy Żaba, Ilustrowana encyklopedia skał i minerałów (Katowice: Videograf II, 2010). 

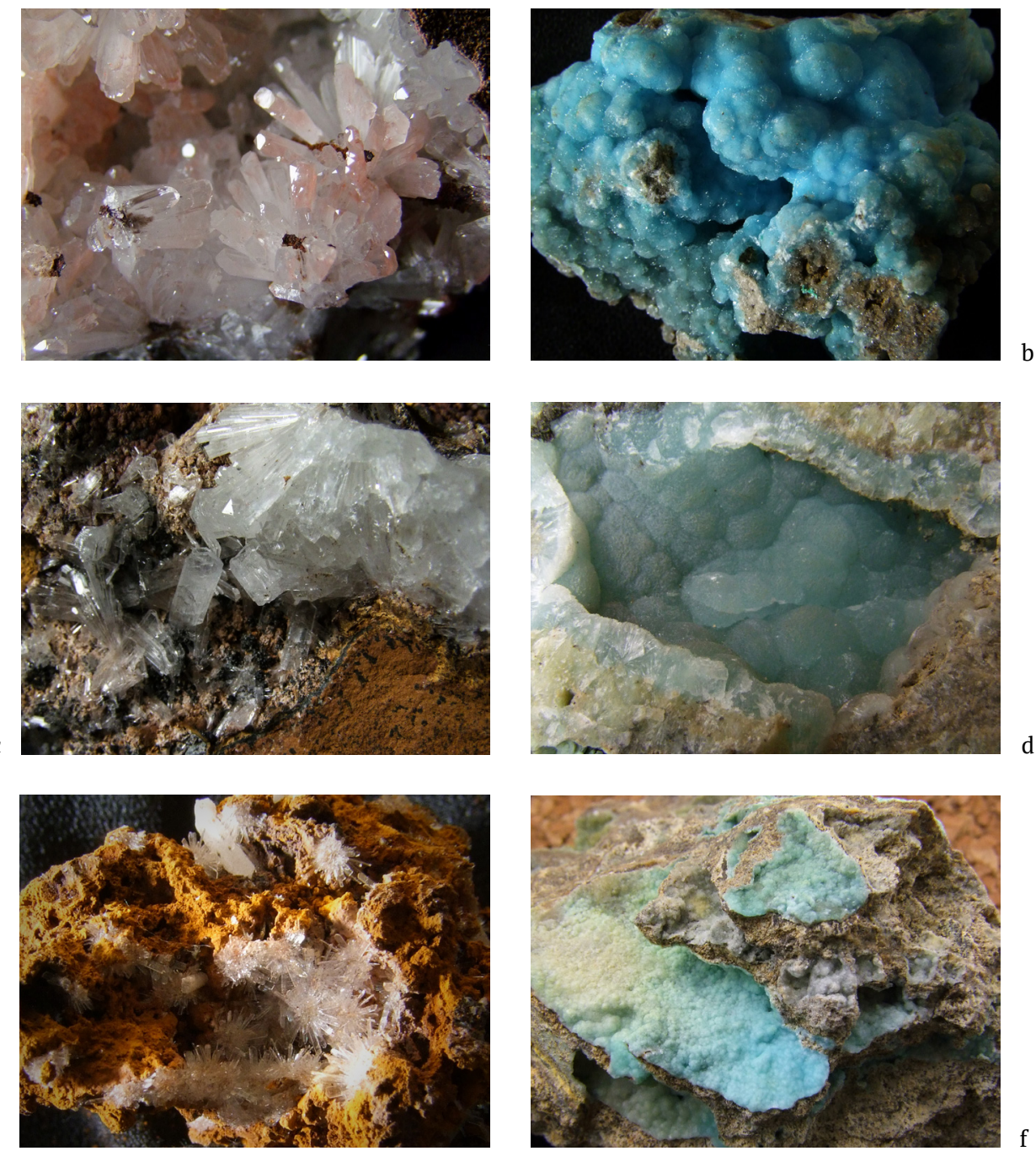

Fot.2. Hemimorfit, $\mathrm{Zn}_{4}\left(\mathrm{Si}_{2} \mathrm{O}_{7}\right)(\mathrm{OH})_{2} \cdot \mathrm{H}_{2} \mathrm{O}$, gromada krzemiany, grupa krzemiany grupowe uwodnione i zawierające inne niekrzemianowe aniony:

a - skupienia rozetowe kryształów, kopalnia Ojuela, Mapimi, Durango, Meksyk,

$\mathrm{b}$ - błękitne naskorupienia, Wenshan, Yunnan, Chiny,

c - skupiska bezbarwnych kryształów, Santa Eulalia, Meksyk,

d - bladobłękitne groniaste naskorupienia, Hauden, Gila County, Arizona, USA,

e - stożkowate skupiska bezbarwnych kryształów, Santa Eulalia, Meksyk,

f - niebieskożółte naskorupienia, Wenshan, Yunnan, Chiny

Fot. A. Tomaszewska-Szewczyk (zbiory własne) 


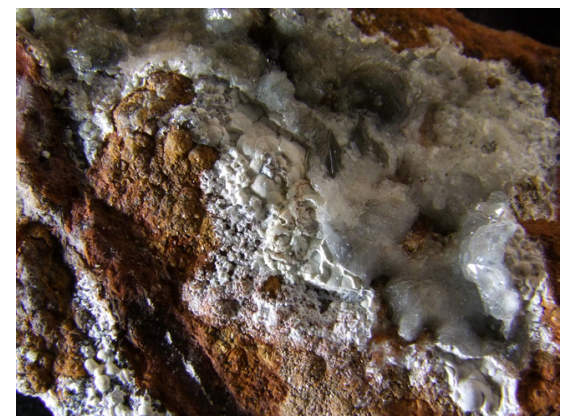

Fot.3. Hydrocynkit, $\mathrm{Zn}_{5}\left[(\mathrm{OH})_{3} /\left(\mathrm{CO}_{3}\right)\right]_{2}$, gromada węglany, grupa rosasytu; kredowe wykwity Fot. A. Tomaszewska-Szewczyk (zbiory własne)

Pierwszy z nich tworzy najczęściej skupienia ziemiste, drobnoziarniste, naciekowe, nerkowate, naskorupienia o budowie groniastej lub ziarnistej. Zwykle jest zielony, niebieskozielony, żółty, biały, ale również bezbarwny, brązowy, niebieski, szary, przybiera także wiele innych zabarwień. Charakteryzuje się połyskiem perłowym lub szklistym. Odmianę smithsonitu zasobną w tlenek żelaza(II) nazywa się monheimitem ${ }^{7}$. Natomiast hemimorfit występuje $\mathrm{w}$ formie naskorupień ziarnistych, zbitych, groniastych, nerkowatych oraz naciekowych, niekiedy tworzy skupiska kryształów o pokroju krótkosłupowym lub igiełkowym i szczotki krystaliczne. Bywa bezbarwny, przybiera również barwę niebieskozieloną, zieloną, białą, żółtą i brązową. Połysk ma od szklistego dla dużych kryształów do matowego dla form zbitych ${ }^{8}$. Obu minerałom może towarzyszyć hydrocynkit, zwany też kwiatem cynkowym (fot. 3), budujący skupienia zbite, ziemiste, sferolityczne, naciekowe, koncentryczne, a także naloty i wykwity. Hydrocynkit jest kruchym minerałem o różnej przezroczystości, matowym lub ziemistym połysku i barwie białej, żółtawej, brunatnej, czasem jasnoniebieskiej lub różowej, niekiedy bywa bezbarwny. Charakteryzuje się niebieską fluorescencją. Opisane minerały powstają wtórnie w strefie utleniania kruszców: sfalerytu (fot. 4) oraz wurtzytu, polimorficznych odmian siarczku cynku. Smithsonit i hydrocynkit są efektem utleniania i karbonatyzacji, hemimorfit zaś metasomatozy, czyli wymieniania składników lepiej rozpuszczalnych przez gazy lub przez krążące roztwory wodne będące nośnikami innych substancji nieorganicznych. Natomiast

Żaba, Ilustrowana encyklopedia, 414.

8 Żaba, Ilustrowana encyklopedia, 175. 

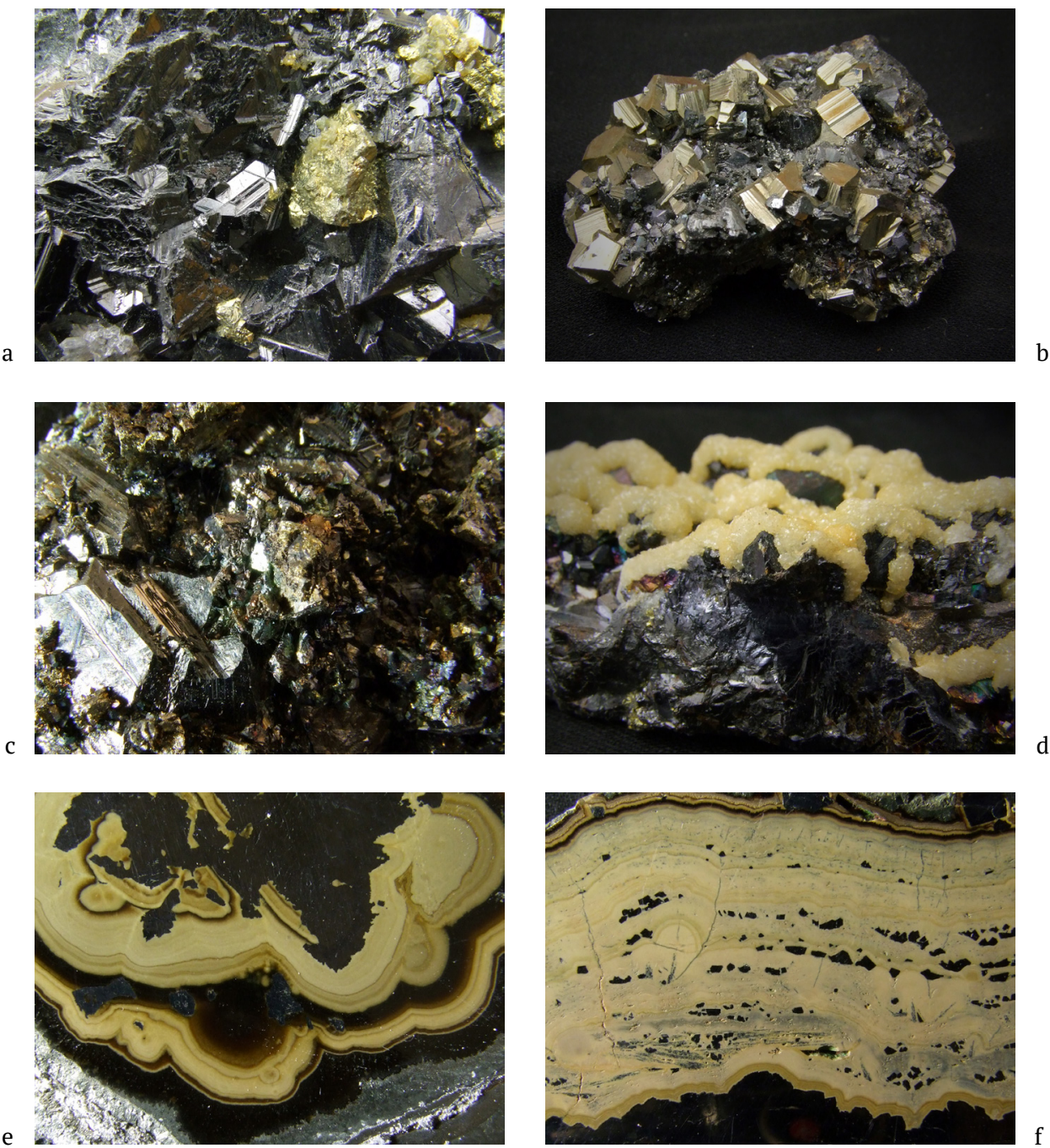

Fot.4. Sfaleryt, (Zn, Fe)S, gromada siarczki, grupa sfalerytu:

a - czarne kryształy szkieletowe z wtrąceniami chalkopirytu (barwa mosiężnożółta), Cavnic, Rumunia,

b - dobrze wykształcone kryształy sfalerytu i pirytu, Cavnic, Rumunia,

c - kryształy sfalerytu i tetraedrytu (kruszce, $\mathrm{Cu}_{12} \mathrm{Sb}_{4} \mathrm{~S}_{13}$ ), Baia Sprie, Rumunia,

d - czarne kryształy sfalerytu pokryte kalcytem z wtrąceniami siarczków miedzi m.in. chalkopirytu, Baia Sprie, Rumunia,

e - blenda skorupowa, drobnokrystaliczna odmiana sfalerytu barwy żółtej i brązowej w towarzystwie galeny i markasytu, kopalnia „Olkusz-Pomorzany”, Olkusz,

f - blenda skorupowa, drobnokrystaliczna odmiana sfalerytu barwy żółtej w towarzystwie galeny i markasytu, kopalnia „Olkusz-Pomorzany”, Olkusz

Fot. A. Tomaszewska-Szewczyk (zbiory własne) 
siarczki zalegają w niższych warstwach litosfery, a znaczenia dla metalurgii nabrały dopiero w drugiej połowie XIX wieku, gdy opracowano technologię hutniczego wytapiania cynku. W strefie wietrzenia rud polimetalicznych zawierających cynk i miedź metale te mogą współtworzyć minerały: aurichalcyt (fot. 5), nazywany niebieskim kalaminem, oraz rosasyt (fot. 6).

a
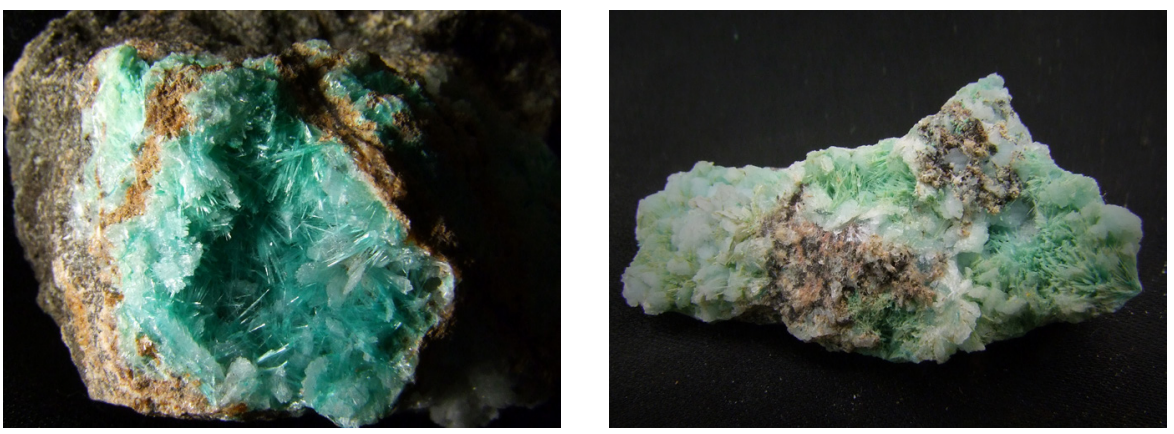

$\mathrm{b}$
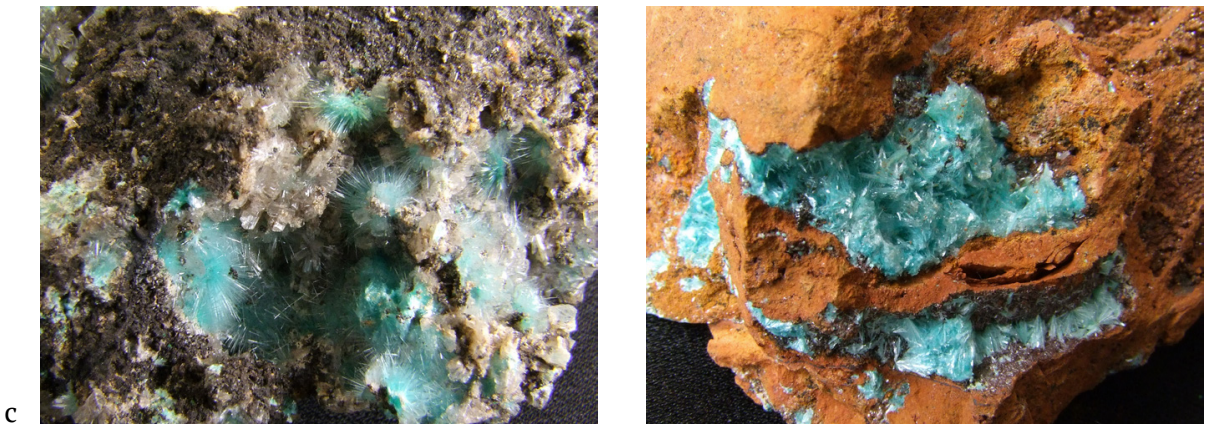

d

Fot.5 Aurichalcyt, wzór chemiczny $(\mathrm{Zn}, \mathrm{Cu})_{5}\left(\mathrm{CO}_{3}\right)_{2}(\mathrm{OH})_{6}$, gromada węglany, grupa rosasytu:

a - zielononiebieskie igły nieprzekraczające $5 \mathrm{~mm}$ w skupieniach promienistych, Gila County, Arizona, USA,

b - zielononiebieskie igły o połysku jedwabistym na hemimorficie, Gila County, Arizona, USA, c - zielononiebieskie igły w skupieniach promienistych, Hauden, Gila County, Arizona, USA,

$\mathrm{d}$ - zielononiebieskie skupienia, kopalnia Ojuela, Mapimi, Durango, Meksyk

Fot. A. Tomaszewska-Szewczyk (zbiory własne)

Wykorzystywanie hutnicze tego typu złóż powodowało, że cynk przechodząc przez kolejne procesy razem z miedzią pozostawał przy niej w na tyle znacznym procencie, by stwarzało to pozory świadomego dodatku. $\mathrm{Na}$ przykład w starożytnych egipskich wyrobach miedzianych z Nagady i Ballas 

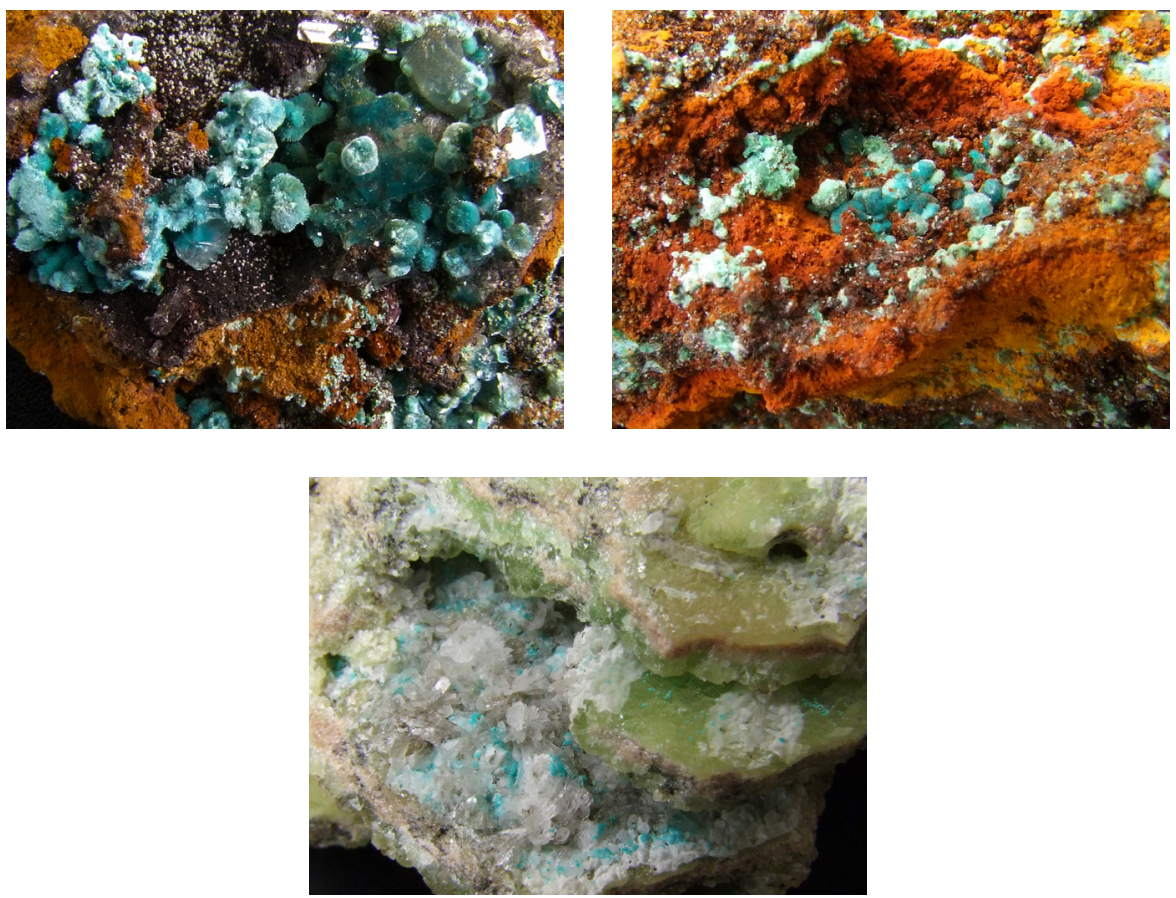

Fot.6. Rosasyt, wzór chemiczny $(\mathrm{Zn}, \mathrm{Cu})_{2} \mathrm{CO}_{3}(\mathrm{OH})_{2}$, gromada węglany, grupa rosasytu:

a - zielononiebieskie skupiska w formie kulistej na limonicie, kopalnia Ojuela, Mapimi, Durango, Meksyk,

b - zielononiebieskie skupiska w formie kulistej na limonicie poprzecinanym malachitem, kopalnia Ojuela, Mapimi, Durango, Meksyk,

c - drobne zielononiebieskie skupiska w formie kulistej na smithsonicie, Hauden, Gila County, Arizona, USA

Fot. A. Tomaszewska-Szewczyk (zbiory własne)

stwierdzono jego zawartość na poziomie 1,5\%, w przedmiotach z terenów Portugalii domieszka cynku wynosi aż $3 \%^{9}$. Jednak są to złoża bardzo rzadko występujące, a stwierdzona ilość cynku jest o wiele za mała, aby znacząco wpłynąć na właściwości otrzymanego stopu. Wytwarzanie mosiądzu musiało więc odbywać się w sposób celowy, a także świadomy, po uprzednim przypadkowym odkryciu samego procesu i stwierdzeniu przydatności technicznej jego produktu.

9 Żaba, Ilustrowana encyklopedia, 273. 


\section{Metalurgia cynku i mosiądzu w Europie oraz wpływ na nią technologii indyjskiej}

W kręgu kultury europejskiej antyczni i średniowieczni metalurdzy nie byli w stanie opanować umiejętności wytapiania cynku ze względu na jego specyficzne właściwości i powszechnie stosowane piece z naturalnym nadmuchem do przetopu wszelkiego rodzaju rud. Trudności w wytapianiu tego metalu wynikają z konieczności stosowania w redukcji jego związków temperatur wyższych od $907^{\circ} \mathrm{C}$, to jest powyżej temperatury jego wrzenia, a parujący cynk spala się w kontakcie z powietrzem. Według Roberta J. Forbesa ${ }^{10}$ jako pierwszy w Europie mógł pozyskać go około 1509 roku Erazm Ebner z Norymbergi, ale powszechnie przyjmuje się, że metodę destylacji cynku niezależnie od siebie opracowali dwaj chemicy: Anton von Swab i Andreas Sigmund Marggraf. Szwed wydestylował go z galmanów w 1742 roku, a dwa lata później z blendy ${ }^{11}$. Drugi z naukowców uzyskał cynk z kalaminu pochodzącego ze złóż w Polsce, Anglii i na Węgrzech w 1746 roku $^{12}$. Jednak genezy technologii, która przyczyniła się do rozwoju w Europie produkcji tego metalu na skalę przemysłową, należy szukać w Indiach.

W lipcu 1738 roku William Champion opatentował metodę otrzymywania cynku z kalaminu z wykorzystaniem retorty pionowej. Przemysłowiec od 1730 roku był związany z Bristol Brass Company, gdzie od 1743 roku rozpoczął produkcję cynku. Trzy lata później założył własną firmę o nazwie Warmley Works, która wkrótce stała się największą przetwórnią metali na świe$\mathrm{cie}^{13}$. Wdrożona przez niego metoda powiela dwunastowieczną technologię stosowaną w indyjskim mieście Zawar ${ }^{14}$. Jego brat John Champion w 1758 roku opatentował metodę destylacji cynku z blendy cynkowej. Wytop z zastosowaniem retorty pionowej był jednak mało wydajny ze względu na brak ciągłości procesu oraz znaczne zużycie węgla (24 tony na 1 tonę cynku) ${ }^{15}$. Kolejnego przełomu technologicznego dokonał Johann Christian Ruhberg -

10 Robert J. Forbes, Studies in Ancient Technology, t. 8 (Leiden: Brill, 1972), 274.

11 Fathi Habashi, Discovering the 8th Metal. A History of Zinc, http://www.azmc.co/en/encyclopedia/discovering-the-8th-metal/ (dostęp 19 marca 2016).

12 Słownik chemiczny (Warszawa: WP, 1995), 365.

13 Reg Harris, The Warmley Works of William Champion, http://www.bittonfamilies.com/WarmleyBrassWorks.html (dostęp 14 lutego 2016).

14 J. S. Kharakwal i L. K. Gurjar, "Zinc and Brass in Archaeological Perspective”, Ancient Asia 1 (2006): 155, doi.org/10.5334/aa (dostęp 14 lutego 2016).

15 Habashi, Discovering. 
opracował technologię wykorzystującą retortę poziomą, co pozwoliło na pracę w systemie ciągłym i zwiększenie wydajności paliwa. W 1798 roku Ruhberg otworzył pierwszą hutę cynku w Wesołej na Górnym Śląsku ${ }^{16}$. Jego metoda zrewolucjonizowała hutnictwo, a Górny Śląsk stał się w XIX wieku największym producentem cynku na świecie. Współcześnie metal ten pozyskuje się w wyniku prażenia, a wydzielone pary są pochłaniane przez ciekły cynk lub ołów. Inną stosowaną metodą jest elektroliza wodnego siarczanu(VI) cyn$\mathrm{ku}$ (II) otrzymywanego w wyniku działania kwasu siarkowego na rozdrobnioną rudę cynkonośną.

Starożytne pisma potwierdzają, że stop mosiężny był otrzymywany w wyniku stapiania miedzi z kopaliną bądź zanieczyszczonym tlenkiem cynku, narostem powstającym w kominach pieców hutniczych w czasie wytapiania rud zawierających domieszki minerałów tego metalu. Należy podkreślić, że mosiądz uznawano za odmianę miedzi, a dodatki związków cynkowych w postaci naturalnej bądź przetworzonej za środki do jej oczyszczania. Starożytni Grecy jednym terminem cadmea (kadmia) nazywali minerały cynku występujące w naturze, bez świadomości, że są to związki jakiegoś metalu, a nawet często tak określali zmieszane jego kopaliny z miedzią; miana tego używali również w odniesieniu do tlenku cynku. Do końca XVIII wieku stapianie miedzi z rudami cynkowymi uważano za sposób uszlachetniania tego metalu i nazywano cementacją ${ }^{17}$ - i była to praktycznie jedyna stosowana metoda wytwarzania mosiądzu. Według Wernera zawartość cynku w stopie mosiężnym otrzymywanym tym sposobem nie przekraczała $30 \%{ }^{18}$. W optymalnych warunkach laboratoryjnych przez stapianie w tyglu grafitowym tlenku miedzi(I) z tlenkiem cynku udało się uzyskać mosiądz o udziale tego metalu sięgającym 34\% ${ }^{19}$. W 1781 roku Anglik James Emerson opatentował metodę sporządzania stopu mosiężnego przez stopienie miedzi z cynkiem²0, ale jeszcze długo mosiądz otrzymywano na drodze cementacji.

16 Habashi, Discovering.

17 Jerzy Piaskowski, „Metalurgia w ‘Historii naturalnej’ G. Pliniusza Starszego”, Archeologia 9 (1957): 112.

18 H. K. Cameron, “Technical Aspects of Medieval Monumental Brasses”, The Archaeological Journal 131 (1974): 225.

19 Sun Shuyun, Han Rubin, "A Preliminary Study of Early Chinese Copper and Bronze Artifacts”, tłum. Julia K. Murray, Early China 9-10 (1983-1985): 268, http://www.jstor.org/stable/23351611 (dostęp 19 marca 2016).

20 Rainer Stahlschmidt, „Das Messinggewerbe im Spätmittelalterlichen Nürnberg“, Mitteilungen des Vereins für Geschichte der Stadt Nürnberg 57 (1950): 125. 


\section{Historia indyjskiej technologii sporządzania stopu mosiężnego}

W ostatnich latach poznajemy coraz więcej badań dotyczących znalezisk z obszaru dzisiejszych Indii i Pakistanu, które światowe początki sporządzania mosiężnego stopu wiążą właśnie z tym obszarem. Z okresu kultury harappańskiej (2200-1500 p.n.e.) zachowało się kilka brązów o zawartości cynku wynoszącej od $0,15 \%$ do $6,04 \%$. W pozostałościach wczesnej epoki żelaza (1200-600 p.n.e.), wśród śladów kultury ceramiki malowanej szarej znaleziono kolejne dowody na wykorzystanie rud cynkowych. W jednym obiekcie zawartość cynku sięga 16,20\%. Składy stopowe tych artefaktów wskazują na ich bardziej eksperymentatorski charakter niż świadome tworzenie kompozycji. W połowie I tysiąclecia p.n.e. rosła liczba przedmiotów o dużej zawartości cynku, pojawiły się też wyroby z mosiężnych stopów. Ich znaleziska pochodzą ze stanowisk w Taksili, Timargarh i Senuwarze. Na pierwszym z wymienionych, w kopcu Bhir odnaleziono wazon ze stopu zawierającego 34,34\% cynku; jest on datowany na czasy przed przybyciem Greków pod wodzą Aleksandra Macedońskiego. Nieznacznie większy udział tego metalu (tj. 35,52\%) stwierdzono w przedmiocie pochodzącym z Senuwaru w dolinie Gangesu. Tak duża ilość cynku w obu artefaktach może dowodzić, że zrobiono je z materiału sporządzonego przez stopienie z miedzią metalu uzyskanego w sposób hutniczy, a nie ze stopu powstałego w technologii cementacji. Jak dotąd wiadomo, że w Zawarze rudy cynkowe wydobywano już w V wieku p.n.e., a cynk w procesie destylacji otrzymywano najwcześniej na świecie; odnalezione ślady tej produkcji pochodzą z IX wieku naszej ery ${ }^{21}$.

Innymi dowodami na zaawansowane metody sporządzania mosiądzu są monety z II-IV wieku o zawartości ponad $28 \%$ cynku w stopie oraz figurki przedstawiające Buddę datowane na V-VI wiek, odnalezione na stanowisku East Nimar w pobliżu Burhanpuru, a odlane metodą na wosk tracony z tworzywa, w którym zawartość tego metalu wynosi $26-27 \%{ }^{22}$.

Z kolei w regionie Himalajów stosowano mosiężny stop bogaty w ołów, nazywany kakatundi, w którym zawartość cynku wahała się od 4\% do 35\%. Dodatek ołowiu korzystnie wpływał na właściwości odlewnicze kompozycji23.

21 Kharakwal, Gurjar, “Zinc and Brass”,148-151.

22 A. S. Bisht, R. C. Jain, "Sixth Century Metal Images from Phophnar - a Scientific Study", Conservation of Cultural Property in India 14-15 (1981-1982): 28-30.

23 Kharakwal, Gurjar, “Zinc and Brass”,152. 
Świadectwa rozwoju produkcji mosiądzu w Indiach odnaleźć można również w źródłach pisanych. Strabon w „Geographica” (15.1.67) ${ }^{24}$ przytacza opowieść Nearchusa, który podróżował po północno-zachodniej części tego kraju $\mathrm{z}$ armią macedońską w IV wieku p.n.e. Wspomina on o naczyniach z mosiądzu, które nie są wykuwane, ale odlewane i gdy spadną na ziemię kruszą się jak ceramika. Nâgârdżuna, indyjski metalurg i alchemik, w traktacie „Rasaratnâkara” opisuje proces otrzymywania mosiądzu zarówno metodą cementacji, jak i destylacji cynku - jest to zatem najwcześniejszy znany tekst o metalurgii tego metalu ${ }^{25}$. Z kilku innych pism również wynika, że cynk hutniczy był w Indiach znany kilka stuleci przed okresem, z którego pochodzą dowody materialne znalezione w Zawarze ${ }^{26}$.

Tak wczesny rozwój umiejętności sporządzania mosiądzu oraz jego powszechne użycie na obszarze Indii i Pakistanu wskazuje na światowe pierwszeństwo Półwyspu Indyjskiego w historii tego stopu. Wiemy, że średniowieczna technologia otrzymywania hutniczego cynku związana z Zawarem wywarła wpływ na podjęcie jego europejskiej produkcji dopiero w pierwszej połowie XVIII wieku, natomiast brakuje powiązania osiągnięć indyjskiej metalurgii mosiądzu z wytwarzaniem mosiężnego stopu w starożytnej Europie.

\section{Początki wytwarzania mosiądzu i jego pierwsze zastosowanie w kulturze materialnej Europy}

Miejsce, a także czas pozyskania mosiądzu oraz wykonania z niego pierwszych wyrobów użytkowych wpływających na rozwój europejskiego mosiężnictwa nie zostały jednoznacznie ustalone. Wydaje się, że nie nastąpiło to w Egipcie, ponieważ do Drugiego Okresu Przejściowego (1640-1532 r. p.n.e.) był technologicznie zacofany w stosunku do Bliskiego Wschodu. Dopiero za czasów Nowego Państwa (1550-1070 r. p.n.e.) wprowadzono nowe technologie, między innymi produkcję brązów, które wyparły stopy miedziano-arsenowe ${ }^{27}$. Być może przyczyną zapóźnienia było również niewystępowanie

24 The Geography of Strabo. Literally translated, with notes, in three volumes (London: George Bell \& Sons, 1903), http://www.perseus.tufts.edu/hopper/text?doc=Strab.+toc\&redirect=true (dostęp 19 marca 2016).

25 Kharakwal, Gurjar, “Zinc and Brass”,153-154.

26 Kharakwal, Gurjar, “Zinc and Brass”,154.

27 John Baines i Jaromir Málek, Wielkie kultury świata. Egipt (Warszawa: Świat Książki, 1996), 42. 
w Egipcie rud cynkonośnych o znaczeniu gospodarczym, gdyż towarzyszą one jedynie złożom ołowiu w Gebel Rosas oraz (w głębszych pokładach) miedzi w Gebel Abu Hamamid.

Najwcześniejsze mosiężne przedmioty znalezione dotychczas na terenie Egiptu, w Karanogu, są datowane na okres rzymski ${ }^{28}$. Mosiądz nie mógł być tu sprowadzany z głębi kontynentu, gdyż afrykańskie ludy sporadycznie eksploatowały złoża zarówno ołowiu, jak i cynku. Przypuszczalnie stop musiał pochodzić z Rzymu, a za pośrednictwem Egiptu docierał - w formie niewielkich gotowych wyrobów, takich jak ornamenty i naczynia - do abisyńskiego Królestwa Aksum będącego ważnym ośrodkiem wymiany z rynkiem w Adulisie ${ }^{29}$.

W brązach palestyńskich spotyka się jedynie niewielką zawartość cynku, pochodzącą z zanieczyszczeń używanych rud miedzi. Na tym terenie również nie znaleziono wyrobów mosiężnych sprzed czasów rzymskich ${ }^{30}$. Odkrycia tego stopu nie dokonano także w Iranie. Jego produkcja na tym terenie rozwinęła się w późniejszym czasie w związku z odkryciem złóż cynku. Z kolei Cypr stał się ważnym ośrodkiem wyrobu stopów mosiężnych dopiero w okresie rzymskim.

Nieco światła na pionierów produkcji mosiądzu rzuca paradoksograficzny tekst Pseudo-Arystotelesa „De mirabilibus auscultationibus” (835.a.62 $\left.{ }^{31}\right)^{32}$ („Opowiadania zdumiewające”). Jest w nim wzmianka o bardzo błyszczącej i jasnej „miedzi Mossynojków”, wytwarzanej nie przez dodawanie cyny, lecz pewnej tam dostępnej ziemi, ale ten, który ją wytapiał, nie podzielił się ową umiejętnością. Lud ten zamieszkiwał wschodnią część południowych wybrzeży Morza Czarnego. Znajdują się tam złoża cynku, dlatego wielu badaczy uważa, że wzmiankowany stop to mosiądz, a opis przedstawia pierwotny sposób jego otrzymywania przez stapianie miedzi z rudą cynkową. Na podstawie tekstu Pseudo-Arystotelesa trudno wywnioskować, kiedy rozwinęła się ta produkcja. Nie można również ustalić, jakiego okresu dotyczy informacja, gdyż najstarsze fragmenty mogą być wyciągiem z pism Arystotelesa, główna część pochodzi z czasów hellenistycznych, a niektóre partie z okresu cesar-

28 Forbes, Studies, 274.

29 Forbes, Studies.

30 Forbes, Studies, 275.

31 Numer strony, kolumny i wiersza według wydania Corpus Aristotelicum Augusta Immanuela Bekkera z lat 1831-1836.

32 Launcelot D. Dowdall, De mirabilibus auscultationibus (Oxford: Clarendon Press, 1909), 835.a.62, https://archive.org/details/demirabilibusaus00arisrich (dostęp 19 marca 2016). 
stwa. Opierając się na materiale archeologicznym, początków wytwarzania mosiądzu można upatrywać z nastaniem I tysiąclecia przed naszą erą ${ }^{33}$.

O dodawaniu do miedzi ziemi, która nadaje jej piękne zabarwienie, wspomina również interesujący się wiedzą przyrodniczą Teofrast (ok. 370-287 r. p.n.e.) w piśmie „Peri lithon” (49) („O kamieniach”) ${ }^{34}$.

Autorem kolejnej relacji, datowanej na IV wiek p.n.e., jest Strabo. W swojej „Geographica” (13.1.56) 35 („Opis ziemi”) zamieszcza wiadomości o kamieniu z okolicy Andejrów, który wypalony staje się żelazem, wytopiony z pewną ziemią sączy „pseudargyros”, a po dodaniu go do miedzi powstaje „oreichalkos”. Przez niektórych komentatorów, między innymi Roberta J. Forbesa $^{36}$, tekst ten jest uważany za bezwartościowy dla historii technologii mosiądzu. Natomiast Aleksander Krawczuk ${ }^{37}$ przytacza interpretację Waltera Leafa, według którego kamień pochodzący z Andejrów to polimetaliczne złoże rud żelazowo-cynkowych, dających w wyniku pierwszego wypalania tlenki tych metali, produkty ogólnie nazwane przez Strabona żelazem. Wytapianie z pewną ziemią - przypuszczalnie z łatwo dostępnym dla metalurgów z Andejrów węglem brunatnym - powoduje przy dużych stratach redukcję do cynku. Rozumując w ten sposób wyjaśniamy, co kryje się pod słowem „oreichalkos”. Powszechnie przyjmuje się, że Grecy przyjęli ten termin dla mosiądzu. Jako oznaczenie metalu błyszczącego jak złoto występuje w jednym z tzw. hymnów homeryckich i u Hezjoda, a sporadycznie także później, w literaturze greckiej okresu klasycznego i hellenistycznego ${ }^{38}$. Takie tłumaczenie tej wzmianki ma poważne konsekwencje, gdyż lokuje znajomość stopu mosiężnego we wczesnym hellenizmie.

W ostatnich wiekach przed naszą erą nieoceniony wkład w rozwój antycznej metalurgii oraz technik obróbki i zdobienia metali wnieśli Celtowie, którzy stworzyli samodzielną i wysoko rozwiniętą kulturę w dorzeczu Renu, Loary i Górnego Dunaju. Uważa się, że używali mosiężnych stopów do pro-

33 Aleksander Krawczuk, „Mosiądz i tlenek cynku w starożytności. Wybór źródeł pisanych”, Archeologia 8 (1956) 2: 440; Andrew N. Sherwood, Milo Nikolic, i John W. Humphrey, Greek and Roman Technology: A Sourcebook: Annotated Translations of Greek and Latin Texts and Documents (London-New York: Routledge, 2003), 211.

34 Krawczuk, „Mosiądz”, 441.

35 The Geography of Strabo.

36 Forbes, Studies, 282-283.

37 Krawczuk, „Mosiądz ”, 442.

38 Aleksander Krawczuk, „Z zagadnień krytyki źródeł do dziejów metalurgii antycznej: mosiądz i cynk w starożytności”, Kwartalnik Historii Kultury Materialnej 5 (1956): 284. 
dukcji swoich wyrobów już w okresie lateńskim ${ }^{39}$ (V-I wiek p.n.e.), a wytwarzane metale były artykułem wymiennym w handlu z Bliskim Wschodem.

Proces wytapiania mosiądzu podlegał ewolucji. Początkowo uzyskiwano go przez stapianie galmanów z miedzią. Z czasem najpierw przetapiano rudy cynkowe, a do sporządzania stopu stosowano tlenek cynku. Przełom ten mógł nastąpić w okresie rzymskim. Wiadomości na temat wytwarzania stopu mosiężnego w tym czasie, pokrywające się z informacjami z innych starożytnych pism, znajdujemy w „Naturalis historia” (34.II.2) („Historia naturalna”) Gajusza Pliniusza Starszego. Według tego źródła mosiądz - „aurichalcum”40 _ otrzymywano na drodze przetapiania miedzi z rudą cynkową lub z narostami piecowymi tlenku cynku, czyli kadmią ${ }^{41}$. Przez wiele stuleci dzieło Pliniusza było źródłem wiedzy metalurgicznej. Powołał się na nie szesnastowieczny autor „De la pirotechnia” („O technice ogniowej”), doświadczony odlewnik ze Sienny, Vannoccio Biringuccio. Georgius Agricola w „De re metallica, libri XII”42 („Metalurgia”) stosuje tę samą nomenklaturę. Andreas Caesalpinus w piśmie „De metallicis libri tres” („Trzy księgi o metalach”) z 1602 roku przytacza całe fragmenty z „Historii naturalnej”, a wybrane z niej informacje podawane były do końca XVIII wieku ${ }^{43}$.

Początkowo mosiądze zawierały tylko kilka procent cynku. Za czasów republiki rzymskiej niektóre monety bito ze stopu, w którym udział tego metalu wynosił jedynie $4 \%{ }^{44}$. Zmiany w składzie stopowym nastąpiły w okresie wczesnego cesarstwa. Oktawian August rozbudował system monetarny, między innymi wprowadził dwie mosiężne monety: sesterce o masie $27 \mathrm{~g}$ oraz trzynastoipółgramowe dupondiusy ${ }^{45}$. W 20 roku p.n.e. w stosowanych stopach zawartość cynku wynosiła już $17,3 \%{ }^{46}$. David A. Scott ${ }^{47}$ zbadał mikrostrukturę monety z tego okresu: wykazuje ona typową zrekrystalizowaną strukturę ziaren zdeformowaną w czasie kucia. Pewne jej cechy wskazują na obróbkę na gorąco albo na zimno po zakończeniu rekrystalizacji. W typowej

39 Forbes, Studies, 279.

40 Nazwa ta, podobnie jak określenie „orichalcum”, wywodzi się od greckiego słowa „oreichalkos”.

41 Piaskowski, „Metalurgia”, 112.

42 Pierwsza łacińska edycja - $1556 \mathrm{r}$.

43 Piaskowski, „Metalurgia”, 99.

44 Forbes, Studies, 279.

45 Jean-Claude Fredouille, Słownik cywilizacji rzymskiej (Katowice: Wydawnictwo „Książnica”, 1996), 178.

46 Encyclopaedia Britannica, t. 4 (Chicago: University of Chicago, 1969), 108.

47 David A. Scott, Metallography and Microstructure of Ancient and Historic Metals (Singapore: Oxford University Press, 1991), 97. 
technologii monety formowano na gorąco. Rzymianie wysoko cenili mosiądz. W okresie panowania Dioklecjana, w latach 285-305, był od sześciu do ośmiu razy droższy od miedzi ${ }^{48}$.

Dioskurides w dziele „De materia medica” („O środkach leczniczych”) wymienia miejsca, gdzie produkowano kadmię - Cypr oraz prowincje rzymskie: Macedonię, Trację i Hiszpanię; można sądzić, że zajmowano się tam również wyrobem mosiądzu. Podaje też opis pozyskiwania kadmi: w czasie wytopu miedzi zbierała się na żelaznych prętach umieszczonych w górnych częściach pieca, skąd ją zgarniano; otrzymywano ją również w hutach srebra ${ }^{49}$. Produktami powstałymi w czasie przetapiania kadmi z węglem drzewnym, a także z miedzią były „spodos” oraz „pompholyks”, czyli czystsze postacie tlenku cynku. Autor podkreśla, że za najlepszą uważano „spodos” cypryjską ${ }^{50}$. Zbieżne relacje znajdujemy w „Historii naturalnej” (34.XXXIV.130-132) Pliniusza Starszego. Wymienia on pewien rodzaj „spodos” nazywany „lauriotis”, który pozyskiwano w czasie przetopu rud srebra. Nazwa ta wywodzi się od miasta Laurion (obecnie Lawrio) w Attyce, gdzie znajdowały się słynne kopalnie eksploatujące złoża srebra znacznie zanieczyszczone minerałami cynku ${ }^{51}$.

Produkcją mosiądzu zajmowali się również mieszkańcy rzymskiej prowincji Germanii. Ważnym jej ośrodkiem był Stolberg w pobliżu Aachen (Akwizgran), gdzie pomiędzy 74 a 77 rokiem zostały odkryte znaczne złoża hemimorfitu. Jego rozkwit przypadł na lata $150-300^{52}$. Później, z początkiem burzliwych dziejów Cesarstwa Rzymskiego i całej Europy, nastąpił powolny upadek prowincji. Już w IV stuleciu germańscy Frankowie zaczęli przenikać do północno-wschodniej Galii, by w końcu przejąć wpływy na całym rozległym obszarze między Loarą a Renem - ze szkodą dla tamtejszych kopalń, ośrodków metalurgicznych i warsztatów.

Wypracowany w starożytności dość zaawansowany proces wytwarzania mosiądzu nie znalazł jednak szerokiego praktycznego zastosowania. Nie stwierdzono obecności cynku w zdecydowanej większości greckich brązów i w wielu analizowanych etruskich stopach miedzi. Od I wieku p.n.e. Rzymianie używali mosiądzu do bicia monet, ale szybko stał się on popularny również w rzemiośle artystycznym wypierając brąz. W II i III wieku n.e. zawartość

\footnotetext{
48 Forbes, Studies, 279.

49 Krawczuk, „Mosiądz”, 443.

Krawczuk, „Mosiądz”, 449.

Krawczuk, „Mosiądz”, 452.

Forbes, Studies, 279.
} 
cynku w monetach spadła, a stopy mosiężne stanowiły około 30\% wytwarzanych stopów miedzi ${ }^{53}$. Jako materiał rzeźbiarski stop ten w pełni został doceniony dopiero w średniowieczu, a w jego upowszechnianiu najważniejszą rolę odegrały wyrosłe z antycznej tradycji warsztaty nadmozańskie.

\section{Produkcja mosiądzu w średniowieczu}

W średniowieczu stopy miedzi z cynkiem nazywano łacińskim słowem „aurichalcum” lub wywodzącym się od niego „auricalcum” ${ }^{54}$. Pojawiły się też nowe regionalne określenia: w języku angielskim ${ }^{55}$ „Cullen Plate” i „latten” (zapisywane również przez jedno „t” oraz z końcówkami -on ${ }^{56}$, -yn), we flamandzkim „lattoen”, a we francuskim „lata” oraz „laiton”57. Polski „mosiądz” to forma zachodniosłowiańskiego wyrazu zapożyczonego od starogermańskiego „massing”. Określenie „mosiądzowy”, używane od XIV stulecia, miało to samo znaczenie co piętnastowieczny przymiotnik „mosiężny”. W tym samym czasie wszedł do użycia wyraz „mosiężnik” oznaczający rzemieślnika sporządzającego przedmioty z mosiądzu ${ }^{58}$. Nazwa „brąz” pojawiła się w tekstach dopiero w pierwszej połowie XVI wieku. Po raz pierwszy użył jej w 1540 roku Vannoccio Biringuccio w „De la pirotechnia”. Określano nią różne stopy miedzi z cyną, ołowiem, a także z cynkiem ${ }^{59}$.

Upadek Imperium Rzymskiego oraz wędrówki ludów spowodowały ekonomiczne osłabienie miast, co zmniejszyło ich rolę w kształtowaniu produkcji. Pogorszyły się także warunki społeczne ograniczając rozwój twórczości artystycznej i doprowadzając do kryzysu rzemiosła. W chwili pojawienia się nowych struktur państwowych dotychczasową rolę ośrodków miejskich

53 Paul Craddock, "The Composition of the Copper Alloys Used by the Greek, Etruscan and Roman Civilizations. 3. The Origins and Early Use of Brass", Journal of Archaeological Science 5 (March 1978): 1-16, doi:10.1016/0305-4403(78)90015-8 (dostęp 16 marca 2016).

54 Termin ten odnajdujemy w traktacie Mnicha Teofila „Diversarum Artium Schedula”.

55 H. K. Cameron, “Technical Aspects of Medieval Monumental Brasses”, The Archaeological Journal 131 (1974): 227.

56 Pojęcie aurichalcum jako równoważne laton jest podane w „De proprietatibus rerum” Bartholomaeusa Anglicusa z ok. 1250 r.

57 Rainer Stahlschmidt, „Das Messinggewerbe im Spätmittelalterlichen Nürnberg“, Mitteilungen des Vereins für Geschichte der Stadt Nürnberg 57 (1950): 126.

58 Andrzej Bańkowski, Etymologiczny słownik języka polskiego, t. 2 L-P (Warszawa: PWN, 2000), 212.

59 Tadeusz Dziekoński, „O zastosowaniu pokładoznawstwa i metaloznawstwa przy badaniu historii technologii miedzi i brązu", w Studia z dziejów górnictwa i hutnictwa, t. 1 (Wrocław: Ossolineum 1957): 133-134. 
przejęły dwór i kościół. Nastąpił kres uniwersalizmu. Każde z napływających plemion wniosło swoje tradycje artystyczne. Nawet kultura i sztuka związana z Kościołem nosiła piętno środowiska politycznego i geograficznego, w którym się kształtowała. Szukano idei i z dużą łatwością przyswajano sobie najrozmaitsze wzorce. Do modelu klasycznego odwoływano się w określonych przedziałach czasowych oraz środowiskach, podczas gdy budowana była nowa jedność.

Jednak dziedzictwo poprzedniego okresu nie zostało utracone. Kontynuowano między innymi rzymską tradycję produkowania mosiądzu. Jej potwierdzeniem jest ustęp w Kodeksie Teodozjusza z 438 roku dotyczący Syryjczyków stacjonujących w Reims, Arles i Trewirze, którzy pracowali przy wyrobie przedmiotów z tego stopu. Rzemiosło to funkcjonowało przez kolejne stulecia. W VIII wieku jurysdykcja burgundzka uregulowała jego działanie według prawa rzymskiego, tak, jak było wcześniej ${ }^{60}$. Potem nastąpił jeden z najważniejszych punktów zwrotnych w historii cywilizacji europejskiej. Frankowie przeszli od organizacji plemiennej do modelu cesarstwa z silną władzą centralną i ich państwo stało się pierwszą potęgą ówczesnej Europy. Od Karola Wielkiego zaczęła się tworzyć nowa jedność kulturowa, budowana na sojuszu papieża i cesarza, i oparta na instytucjach monarchii Franków oraz na Kościele rzymskim. Nadszedł nowy złoty wiek, czas odnowy.

Dziedzictwo antyczne, dorobek Kościoła, osiągnięcia sztuki północy Europy - wszystko to łączy się w jeden nurt i służy odrodzonej idei jedności i powszechności. Spuścizna antyku jest narzędziem, chrześcijaństwo normą, a północne wpływy wspomagają ten unifikacyjny proces. Towarzyszy mu przepływ ludzi, dzieł i idei. Działalność artystyczna skupia się wokół licznie powstających lub dźwigających się z upadku katedr i klasztorów. Podupadłe kopalnie i warsztaty metalurgiczne za rządów Karola Wielkiego, ożywczo wpływających na wszystkie dziedziny sztuki i rzemiosła, wchodzą w okres rozkwitu. Zaspokajają wielki popyt wywołany powstawaniem opactw i kościołów, wyposażanych - jak wynika z zachowanych inwentarzy - w sprzęt zapewniający odpowiedni przebieg liturgii oraz upiększający jej miejsce: świeczniki, krzyże, antepedia, kielichy, pateny, relikwiarze, kadzielnice i różnorakie naczynia pomocnicze, konewki, wiaderka, kubki i dzbanki. Załamanie się cesarstwa Franków w połowie IX wieku powstrzymało ruch zjednocze-

60 Forbes, Studies, 282. 
niowy. Jednak wzbudzony proces dał podstawę pierwszemu wielkiemu i powszechnemu stylowi po upadku cywilizacji antycznej - romanizmowi.

Najwcześniej przemysł metalurgiczny średniowiecznej Europy odrodził się nad Mozą. Jego zalążkiem były warsztaty z okresu rzymskiego w Anthée. Najsłynniejszymi ośrodkami produkcji mosiądzu były okolice Dinant, Givet aż po Liège (Leodium) na północy oraz rejon Kolonii. Korzystano z występujących na tym obszarze zasobów rud cynku, natomiast miedź początkowo sprowadzano z Antwerpii, później z Saksonii, z gór Harzu. Wyroby mosiężne wykonywano w Dinant, Huy, Namur, Liège, Brukseli, Mechelen, Antwerpii, Turnai, Brugii, Maastrich i Kolonii. W Dinant rozwinął się znany w całej Europie rynek sprzedaży tych przedmiotów, w efekcie w XIV wieku od nazwy tego miasta popularnie zaczęto je określać mianem „dinanterie”. Świetnie rozwijający się ośrodek sztuki metalurgicznej i rzemieślniczej w 1466 roku najechał i spustoszył książę burgundzki Karol Zuchwały (Śmiały), syn Filipa III Dobrego. Całkowicie zniszczone Dinant opuściło wielu doskonałych rzemieślników, którzy osiedlili się w Brukseli, Tournai, Namur, Brugii, Mechelen, Huy i Norymberdze.

Dobre wyobrażenie o rozwiniętej produkcji odlewniczej na terenie nadmozańskim dają inwentarze klasztorów z dzisiejszej Belgii i północnej Francji, których dzieje sięgają X stulecia. O jej wysokim poziomie artystycznym i technicznym osiągniętym na początku XII wieku świadczy chrzcielnica wykonana przez Reniera de Huy na zamówienie opata Hellinusa do kościoła Notre-Dame w Liège (obecnie w kościele Saint-Barthélemy). Misa, dekorowana scenami o tematyce wiążącej się z chrztem, odlana została ze stopu mosiężnego zawierającego miedź (77,20\% stopu), cynk (15,27\%), cynę (4,96\%) i ołów $(1,70 \%)^{61}$; zbliżony skład stopowy mają podtrzymujące ją figury wołów. Z nadmozańskim rzemiosłem metalowym tego okresu związali się także inni znani twórcy: Godefroid de Clair i Nikolas de Verdun. Z mosiądzu były sporządzane sprzęty liturgiczne, naczynia codziennego użytku, ale także płyty nagrobne. Rynkami zbytu gotowych wyrobów oraz mosiądzu i półfabrykatów w postaci blach i drutu były północne Niderlandy oraz tereny obecnej Francji i Anglii, wysyłano je także przez Koblencję w dół Renu, na południe Europy do Hiszpanii, Portugalii i Włoch, na wschód do Polski i na północ do Skandynawii.

${ }^{61}$ Jerzy Piaskowski, Technologia dawnych odlewów artystycznych (Kraków: Wydawnictwo Instytutu Odlewnictwa, 1981), 137. 
Wschodnia część dawnego państwa Franków, która na mocy traktatu z Verdun została przyznana Ludwikowi Niemieckiemu, stała się podstawą budowania nowej państwowości. Po okresie najazdów, za panowania Ottonów z dynastii saskiej powstały warunki do ponownego ożywienia działalności artystycznej i rzemieślniczej. W XI wieku w Saksonii zaczęło się tworzyć drugie ważne centrum produkcji mosiądzu i rzemiosła mosiężnego wczesnośredniowiecznej Europy, odpowiadając na wzrastające zapotrzebowanie. Jego rozwój wspomagały wielkie złoża miedzi w Goslarze koło Hildesheim, napływający specjaliści: górnicy, metalurdzy oraz rzemieślnicy z regionu nadmozańskiego, a także pochodzące stamtąd rudy cynku. Z postępem osiągniętym w tamtejszych ośrodkach ściśle wiązało się powstanie nowych miejsc wyrobu mosiądzu w Saksonii. Najważniejszymi ośrodkami tej produkcji stały się Hildesheim oraz Magdeburg. Najbardziej znanym dziełem tego okresu są drzwi, które biskup Bernwald kazał sporządzić dla wzniesionego przy założonym przez siebie klasztorze benedyktyńskim kościoła Sankt Michael w Hildesheim. Ukończone w 1015 roku, prawie pięciometrowej wysokości (4,72 m) skrzydła pokryte są scenami ze Starego i Nowego Testamentu ${ }^{62}$. Odlane zostały z brązu ołowianego z dużą zawartością cyny i cynku (tab. 1).

Tabela 1. Skład stopowy drzwi z 1015 roku z kościoła Sankt Michael w Hildesheim

\begin{tabular}{|c|c|c|c|c|c|c|c|c|}
\hline Lp. & Skrzydło & $\mathbf{C u}$ & $\mathrm{Pb}$ & $\mathbf{S n}$ & $\mathrm{Zn}$ & $\mathrm{Fe}$ & $\mathrm{As}$ & $\mathbf{N i}$ \\
\hline 1 & lewe & 76,56 & 11,25 & 7,33 & 4,30 & 0,21 & 0,15 & 0,12 \\
\hline 2 & prawe & 77,22 & 8,64 & 8,50 & 5,04 & 0,28 & 0,18 & 0,08 \\
\hline
\end{tabular}

Źródło: Arthur Peltzner, „Geschichte der Messingindustrie und der künstlerischen Arbeiten in Messing (Dinanderies) in Aachen und den Ländern zwischen Maas und Rhein von der Römerzeit bis zur Gegenwart“, Zeitschrift des Aachener Geschichtsvereins 30 (1908): 253.

Około 1020 roku dla tego samego kościoła wykonano kolumnę o wysokości 3,81 m i średnicy 58,4 cm ${ }^{63}$, wzorowaną na triumfalnych kolumnach Trajana i Marka Aureliusza z okresu rzymskiego. Na spiralnie poprowadzonym

62 Ursula Mende, Die Bronzetüren des Mittelalters 800-1200 (München: Hirmer Verlag, 1994), $28-33$.

63 Sculpture from Antiquity to the Present Day from the Eighth Century BC to the Twentieth Century, red. Georges Duby, Jean-Luc Daval (Köln: Taschen, 2002), 270. 
fryzie wyobrażone są sceny z życia Chrystusa. Z kolei w Magdeburgu około 1004 roku odlane zostały płaskorzeźby dla arcybiskupa Giselera.

Sztukę powstającą w okresie ottońskim podporządkowano idei odnowy cesarstwa. Była wynikiem ścisłego powiązania władzy świeckiej i kościelnej. Mecenat sprawował cesarz, biskupi oraz opaci. Ponieważ funkcję najważniejszych ośrodków twórczych pełniły klasztory, rozwijająca się działalność artystyczna była skoncentrowana na tworzeniu sztuki kościelnej, budowaniu świątyń i wyposażaniu ich.

We wczesnym średniowieczu powstały również - nie na tak wysokim poziomie i nie na taką skalę jak nad Mozą i w Saksonii - lokalne ośrodki produkcji mosiądzu i wyrobów mosiężnych, w reakcji na miejscowe potrzeby. Na przykład na ziemiach polskich na przełomie X i XI wieku w Kruszwicy pojawiły się wyroby z mosiądzu, a z połowy XI stulecia pochodzą ślady ich wytwarzania. W drugiej połowie XI wieku produkcja ta podupadła w wyniku najazdu czeskiego, wojen z Brzetysławem i powstań ludowych, ale później została wznowiona i rosła aż do końca XII stulecia ${ }^{64}$. Wśród znalezionych na tym stanowisku wyrobów ze stopów miedzi było tyle samo przedmiotów mosiężnych i brązowych ${ }^{65}$. Z mosiądzu wykonana została większość pierścionków i część kabłączków skroniowych ${ }^{66}$. Analiza stopowa wykazała, że w niektórych artefaktach średnia zawartość cynku sięgała nawet 17,5\% ${ }^{67}$.

Stulecia XII i XIII były okresem wzrostu produkcji, także rzemieślniczej, narastającego utowarowienia gospodarki oraz znacznego ożywienia handlu, co powodowało zwiększenie popytu na metale. Rozpowszechnianie się technologii wyrobu mosiądzu w XIII wieku potwierdza przekaz jednego z najwszechstronniejszych uczonych średniowiecza, dominikanina Alberta Wielkiego, w którym zaświadcza, że w Paryżu, Kolonii oraz innych miejscach, gdzie bywał, popularnością cieszy się „aurichalcum” otrzymywane z miedzi oraz z kamienia zmielonego na puder nazywanego „calamina”68. Największymi producentami mosiądzu aż do połowy XVI wieku były nadal ośrodki nadmozańskie oraz Kolonia.

64 Barbara Hensel-Moszczyńska, „Wyroby z miedzi i jej stopów z wczesnośredniowiecznej Kruszwicy”, Slavia Antiqua 28 (1981/1982): 186.

65 Hensel-Moszczyńska, „Wyroby”, 195.

66 Hensel-Moszczyńska, „Wyroby”, 148.

67 Hensel-Moszczyńska, „Wyroby”, 136.

68 Arthur Peltzner, „Geschichte der Messingindustrie und der künstlerischen Arbeiten in Messing (Dinanderies) in Aachen und den Ländern zwischen Maas und Rhein von der Römerzeit bis zur Gegenwart“, Zeitschrift des Aachener Geschichtsvereins 30 (1908): 257. 
Do końca średniowiecza rudy miedzi, ze względu na niedużą ilość wytapianego metalu w stosunku do skały płonnej i wiążące się z tym trudności transportowe, były przetapiane w pobliżu miejsc wydobycia. W końcu XII i w XIII wieku mocno eksploatowano złoża miedzi w górach Herzu koło Goslaru, przede wszystkim w masywie góry Rammelsberg. Intensywnie wykorzystywano złoża w okolicach Freibergu i Miśni. Największy w tym czasie region górniczy rud nieżelaznych z ośrodkiem w słynnej Kutnej Horze stanowiła Wyżyna Czesko-Morawska. Ważny obszar wydobycia i przetwórstwa znajdował się na Słowacji, nad Hornem, w ówczesnym państwie węgierskim; Bańska Bystrzyca, gdzie pozyskiwano miedź, oraz okoliczne ośrodki tworzyły tak zwane dolnowęgierskie miasta górnicze. Kopaliny miedzionośne eksploatowano na Spiszu, w górnowęgierskich miastach górniczych, z ośrodkami w Gelnicy i Smolniku. Wymienionym regionom ustępowały dopiero rozwijające się wówczas kopalnie w Tyrolu, Styrii, Karyntii, Salzburgu, Mansfeldzie, Turyngii i w szwedzkim w Kopparbergu ${ }^{69}$. Ich dynamiczny rozwój nastąpił w połowie XV wieku.

$\mathrm{Na}$ ziemiach polskich produkcja metali nieżelaznych - poza ołowiem - nie dorównywała największym ośrodkom europejskim. Duże znaczenie miała eksploatacja złóż cynkowo-ołowianych (między innymi galmanów) na obszarze śląsko-krakowskim. Marcin z Urzędowa, lekarz i farmaceuta żyjący w XVI wieku, odnotował, że w Olkuszu i Tarnowskich Górach w trakcie odciągania srebra od ołowiu zbierano „tutię” (tlenek cynku ${ }^{70}$. Rudy miedzi pozyskiwano w regionie świętokrzyskim w okolicach Miedzianej Góry i Miedzianki, w Tatrach Zachodnich, a także na Dolnym Śląsku w rejonie Bolesławca, Złotoryi, w Górach Kaczawskich, Sowich i Łomnickich (Miedzianka, Stara Góra) ${ }^{71}$. O eksploatacji tych złóż, uwarunkowanej stanem ówczesnej techniki, decydowały warunki geologiczne, a więc głównie łatwy dostęp. Z rodzimych zasobów czerpano jednak na mniejszą skalę. Najważniejszym źródłem zaspokajania krajowego zapotrzebowania na miedź był jej import. Dzięki ustabilizowanym od połowy XIII wieku stosunkom handlowym Kra-

69 Danuta Molenda, „Górnictwo kruszcowe na terenie złóż śląsko-krakowskich do połowy XVI wieku”, w Studia z dziejów górnictwa i hutnictwa, t. 8, red. Jan Pazdur (Studia i Materiały z Historii Kultury Materialnej, t. 15, red. Aleksander Gieysztor) (Wrocław-Warszawa-Kraków: Ossolineum, Wydawnictwo PAN, 1963): 50-51.

70 Krawczuk, „Mosiądz”, 453.

71 Danuta Molenda, „Górnictwo kruszców”, w Zarys dziejów górnictwa na ziemiach polskich, red. Jan Pazdur, t. 1 (Katowice: Wydawnictwo Górniczo-Hutnicze, 1960): 120-121. 
kowa z Węgrami rozwijała się wymiana polskiego ołowiu, a także soli, na słowacką miedź i srebro.

Ożywienie wydobycia na ziemiach polskich przypadło na lata osiemdziesiąte XV wieku. W działalności tej uczestniczyło przede wszystkim mieszczaństwo, ale również szlachta, dostojnicy państwowi i duchowieństwo. Do czołowych przedsiębiorców, działających także poza granicami Królestwa Polskiego, głównie na Śląsku i Węgrzech, należały znamienite rody: Salomonów, Bonerów, Szydłowieckich i najbardziej aktywnych na tym polu Turzonów. Z Janem Turzonem wiąże się huta miedzi w Mogile koło Krakowa, której funkcjonowanie jest poświadczone od 1469 roku do końca lat dwudziestych XVI wieku ${ }^{72}$. Rudy miedzi do przetopu pochodziły z jego kopalń w Tatrach, koło Bańskiej Bystrzycy (Stary Hory, Piesky i Spania Dolina) oraz na Spiszu koło Smolnika i Glenicy ${ }^{73}$.

Średniowieczna baza surowcowa była bogata, a warunki społeczne i ekonomiczne sprzyjały rozwojowi rzemiosła. W efekcie rosło zapotrzebowanie na metale i ich stopy o właściwościach dopasowanych do ściśle określonych celów.

\section{6. Średniowieczna technologia mosiądzu \\ i technik stosowanych w mosiężnictwie w świetle traktatu Teofila Prezbitera}

Datowany na początek XII wieku traktat „Diversarum artium schedula”74 („O sztukach rozmaitych ksiąg troje”) jest szczegółowym i fachowym kompendium ówczesnej wiedzy na temat technologii i technik stosowanych w rzemiośle artystycznym, wyrosłym na znajomości tradycji antycznej zachowanej w „Historii naturalnej” Pliniusza Starszego. Jego autor, żyjący na przełomie XI i XII stulecia benedyktyn Teofil Prezbiter, nazywany też Teofilem Mnichem, jest identyfikowany z Rogerem von Helmarshaus ${ }^{75}$, złotnikiem wykształconym w rejonie nadmozańskim.

72 Danuta Molenda, „W sprawie badań huty miedzi w Mogile pod Krakowem w XV i XVI wieku”, Przegląd Historyczny 66 (1975) 3: 369.

73 Molenda, „W sprawie”, 373.

74 Znane też pod tytułem „De diversis artibus”. Zachowały się dwa wczesne egzemplarze: w Österreichische Nationalbibliothek w Wiedniu i w Herzog August Bibliothek w Wolfenbüttel.

75 Erhard Brepohl, Theophilus Presbyter und die mittelalterliche Goldschmiedekunst (WienKöln-Graz: Böhlau-Verlag, 1987), 20, 24. 
Trzecia księga traktatu dotyczy głównie obróbki metali i wytwarzania metalowych przedmiotów. Znajdujemy w niej wiele cennych wskazówek dotyczących produkcji mosiądzu i mosiężnych wyrobów w wiekach średnich. Między innymi w krótkiej informacji na temat rud używanych do wytopu miedzi autor podaje ${ }^{76}$, że są one zielonej barwy i znacznej twardości, występują w postaci żył i towarzyszą im rudy ołowiu. Jerzy Piaskowski ${ }^{77}$ identyfikuje je z malachitem, jest to jednak zbyt duże uproszczenie.

Miedź łączy powinowactwo z siarką, dlatego jej rudy w stanie pierwotnym występują głównie w połączeniu z tym minerałem. Siarczki, między innymi chalkozyn, covellin, bornit oraz najbardziej rozpowszechniony chalkopiryt (fot. 7a, b, d, e), wchodzą w skład masy mineralnej skał głębinowych, która w warunkach strefy przypowierzchniowej skorupy ziemskiej jest chemicznie nietrwała.

Wysoki potencjał utleniający tego środowiska powoduje powstawanie związków tlenkowych i węglanowych. Jest to strefa naturalnego utleniania, gdzie występują głównie kupryt, malachit i azuryt (fot. 8). Pod wpływem kwasu siarkowego(VI) powstają kolejne połączenia: chalkantyt (fot. 9a) i brochantyt (fot. 9b), które przechodzą w roztwory, a napotykając na nowe warunki, na przykład podskórne wody będące nośnikami jonów żelaza, redukują się do postaci metalicznej (fot. 9c). Procesy te zachodzą w strefie cementacji. Oczywiście w wyniku procesów geologicznych i morfologicznych opisany układ występowania minerałów ulega zaburzeniu. Ponadto w strefie wietrzenia kruszców powstają także inne połączenia miedzi, na przykład krzemiany - chryzokola (fot. 8a, b) i dioptaz (fot. 9d), halogenki - atacamit (fot. 9e), fosforany - libethenit (fot. 9f). Miedź rodzima jest surowcem gotowym do obróbki. Z rud tlenkowych i węglanowych można go uzyskać w prosty sposób metodą pirometalurgiczną. Natomiast otrzymywanie miedzi z kruszców było dużo bardziej skomplikowane i wiązało się z wielokrotnym ich prażeniem i przetopem, ale ta umiejętność przeróbki została opanowana już w epoce $\mathrm{brązu}^{78}$. Mówiąc więc o rudach wykorzystywanych w tym okresie nie można wymieniać jednego minerału miedzi barwy zielonej - malachitu. Są one często przemieszane i jest wiele rud odpowiadających opisowi w traktacie.

76 Teofil Prezbiter, Diversarum artium schedula. Średniowieczny zbiór przepisów o sztukach rozmaitych, tłum. Stanisław Kobielus (Kraków: Tyniec. Wydawnictwo Benedyktynów, 1998), 117.

77 Jerzy Piaskowski, „Technologia metali w XI-XII w. w świetle książki Teofila ‘O sztukach rozmaitych ksiąg troje’”, Studia i Materiały z Dziejów Nauki Polskiej 10 (1955) 1: 145.

78 Dziekoński, „O zastosowaniu”, 140, 141. 
a
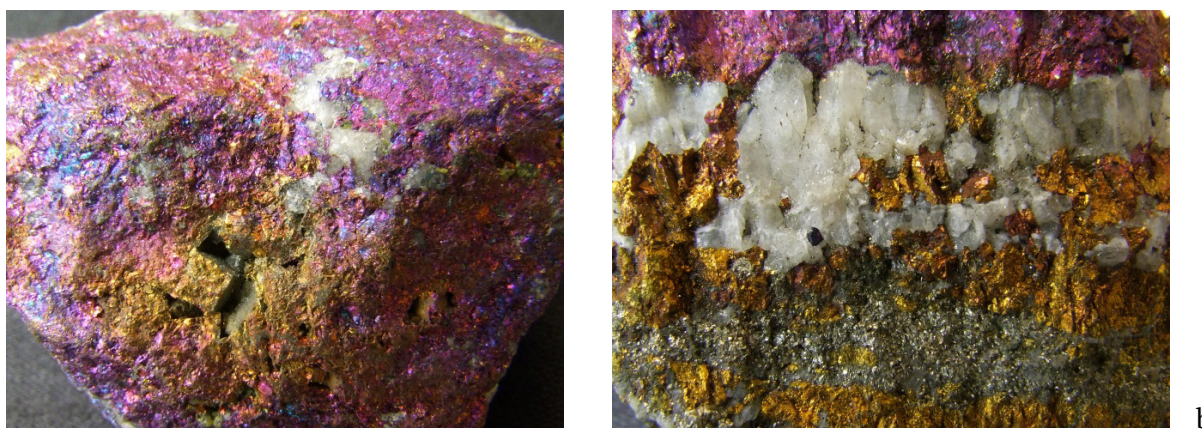

$\mathrm{b}$
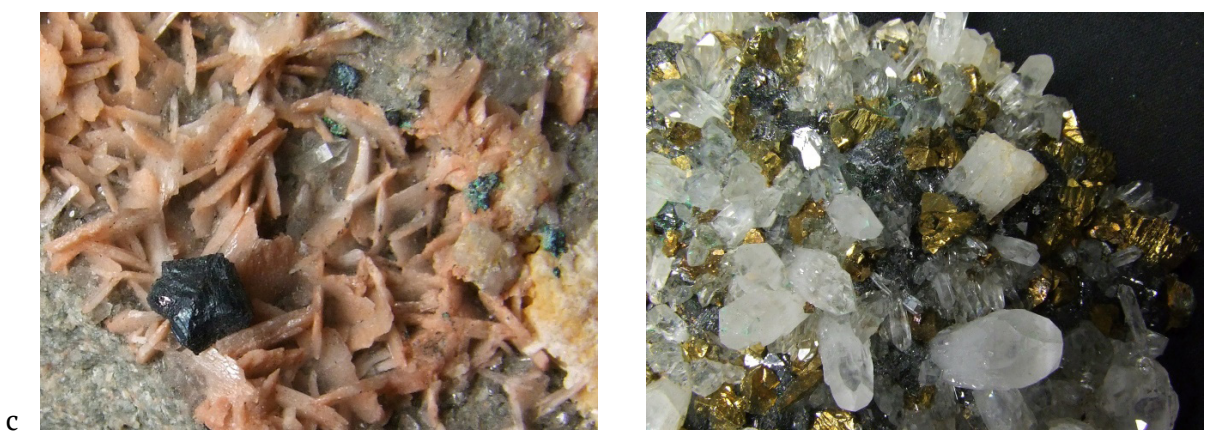

d

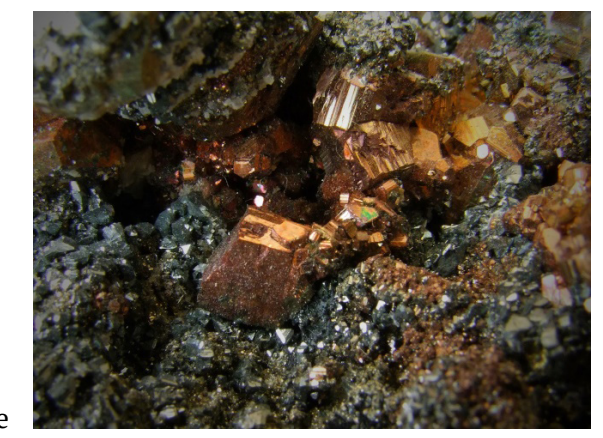

Fot.7. Gromada siarczki i siarkosole:

bornit - $\mathrm{Cu}_{5} \mathrm{FeS}_{4}$, covellin - CuS, chalkopiryt - $\mathrm{CuFeS}_{2}$, tetraedryt - $(\mathrm{Cu}, \mathrm{Fe})_{12} \mathrm{Sb}_{4} \mathrm{~S}_{13}$ a - chalkopiryt, bornit i covellin, „pawia ruda” (stara nazwa górnicza), Brazylia, b - chalkopiryt, bornit i covellin, Francja,

c - kryształy bornitu na barycie, Dseskasgan, Kazachstan,

d - kryształy chalkopirytu wśród sfalerytu i kwarcu, Cavnic, Rumunia, e - kryształy chalkopirytu i tetraedrytu, Cavnic, Rumunia

Fot. A. Tomaszewska-Szewczyk (zbiory własne) 

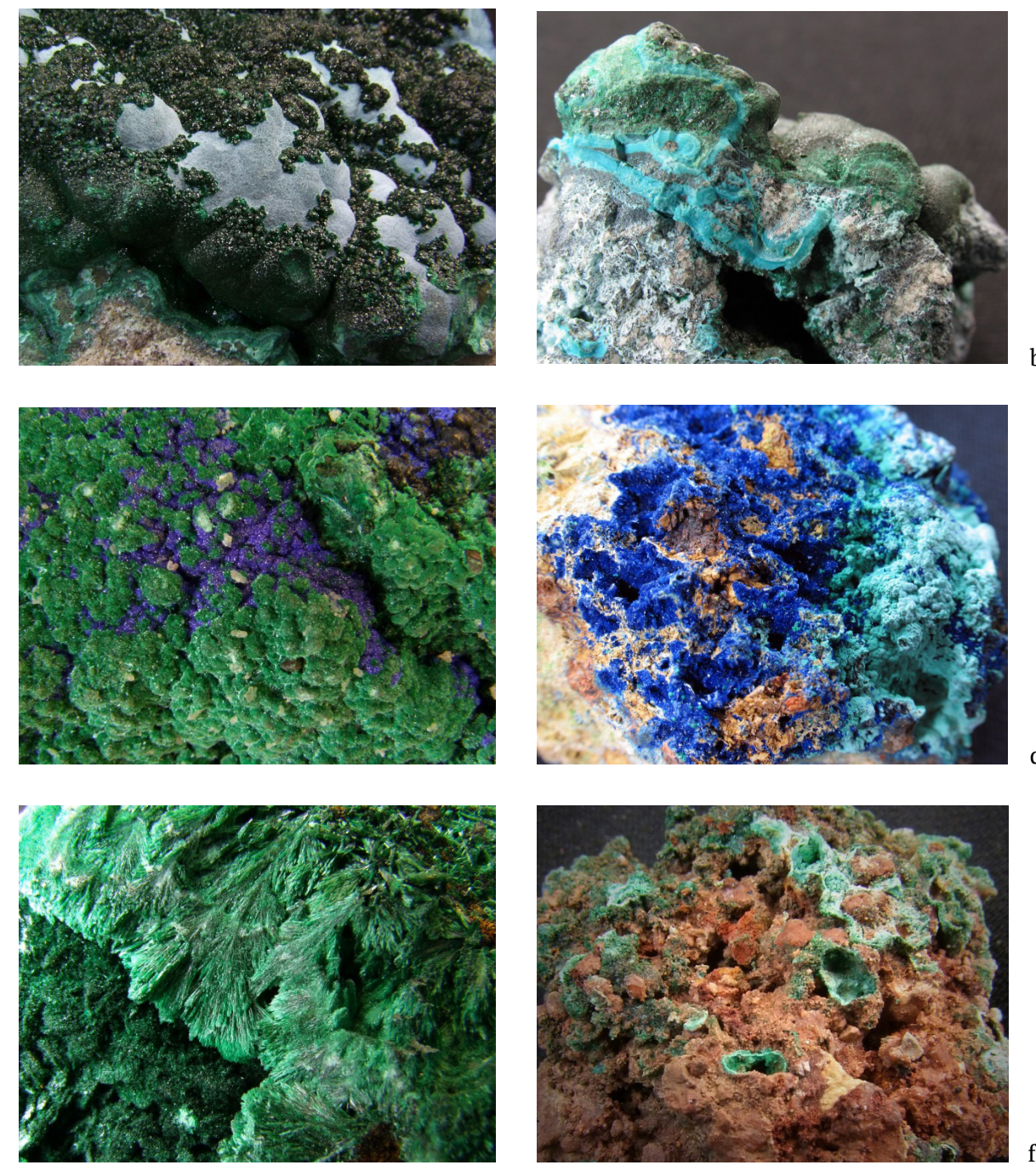

Fot.8. Minerały strefy naturalnego wietrzenia rud siarczkowych miedzi:

malachit - $\mathrm{Cu}_{2} \mathrm{CO}_{3}(\mathrm{OH})_{2}$, gromada węglany uwodnione i zawierające grupy hydroksylowe, azuryt - $\mathrm{Cu}_{3}\left(\mathrm{CO}_{3}\right)_{2}(\mathrm{OH})_{2}$, gromada węglany uwodnione i zawierające grupy hydroksylowe, kupryt - $\mathrm{Cu}_{2} \mathrm{O}$, gromada tlenki, chryzokola - $\mathrm{Cu}_{2 \mathrm{x}}\left(\mathrm{Al}, \mathrm{Fe}^{3+}\right)_{\mathrm{x}} \mathrm{H}_{2 \mathrm{x}} \mathrm{Si}_{2} \mathrm{O}_{5}(\mathrm{OH})_{4} \cdot \mathrm{nH}_{2} \mathrm{O}$, gromada krzemiany, a - dwie generacje malachitu z błękitnym nalotem chryzokoli, Kolwezi, Katanga, Kongo,

b - malachit poprzerastany chryzokolą, Republika Kongo,

c - malachit z azurytem, Aouli, Maroko

d - azuryt z nalotem malachitu, Toussit, Maroko,

e - malachit skupienia włókniste, kopalnia Kalukuluku, Kongo,

f - kupryt z nalotem malachitu, Almeria, Hiszpania

Fot. A. Tomaszewska-Szewczyk (zbiory własne) 
a
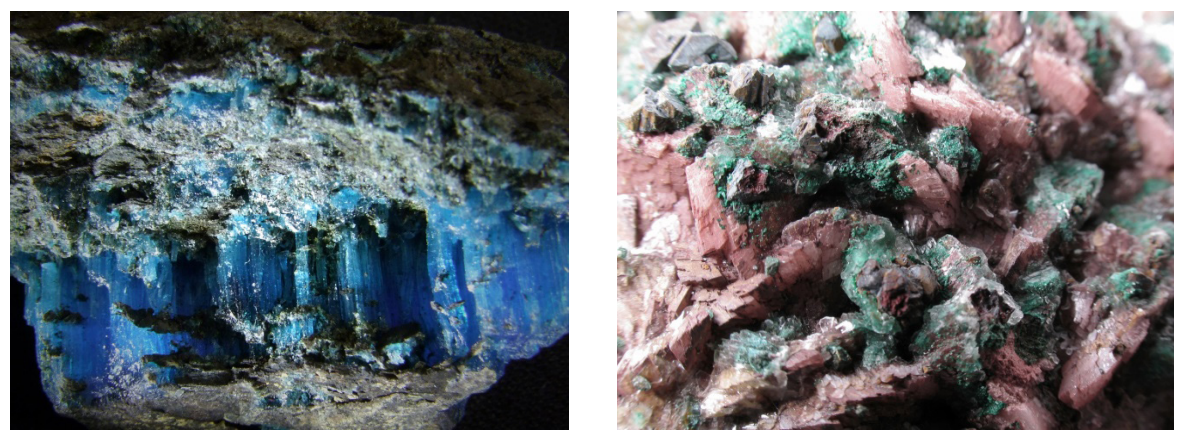

b
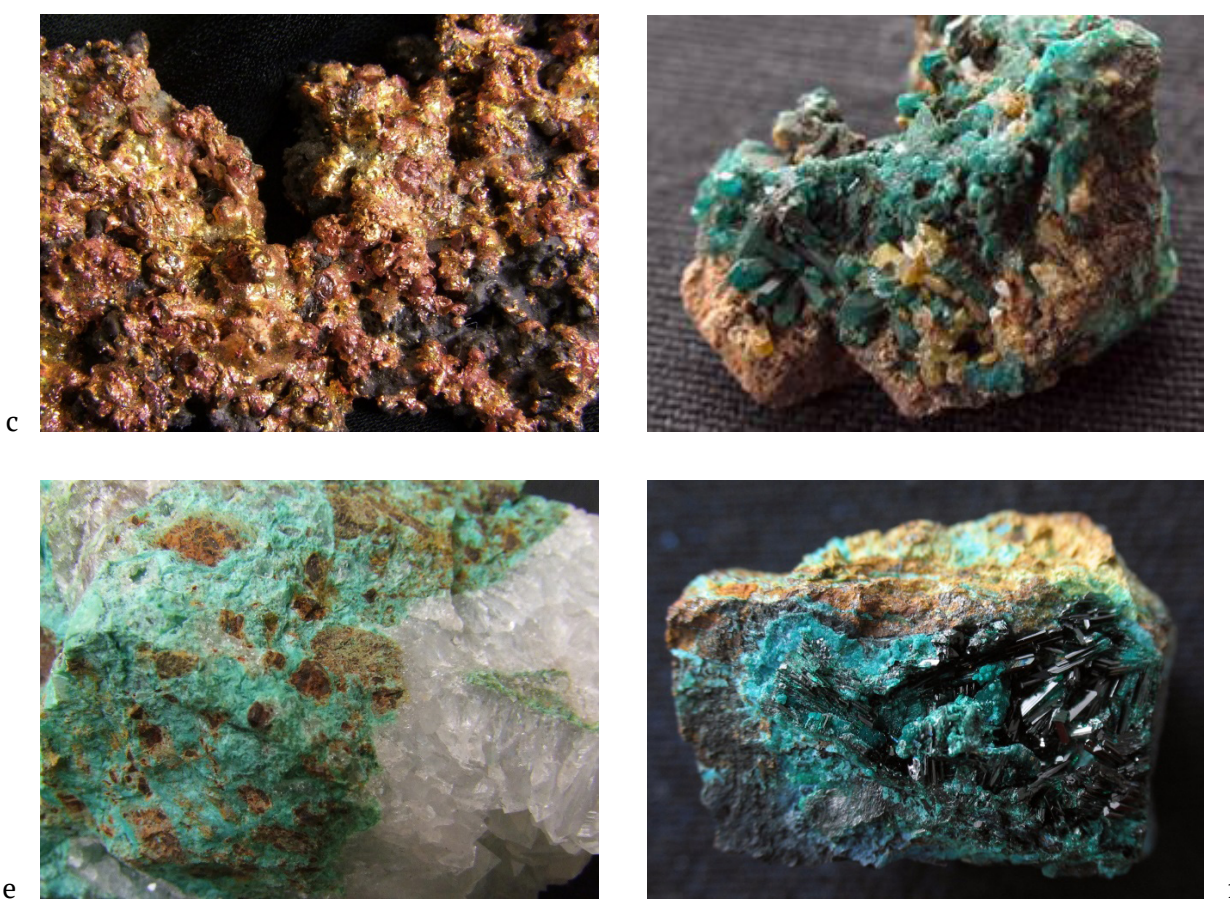

Fot.9. Przykłady minerałów występujące w strefie wietrzenia siarczków miedzi:

a - chalkantyt $\mathrm{CuSO}_{4} \cdot 5 \mathrm{H}_{2} \mathrm{O}$, gromada siarczany, grupa chalkantytu,

b - brochantyt $\mathrm{Cu}_{4} \mathrm{SO}_{4}(\mathrm{OH})_{6}$, gromada siarczany, grupa jarosytu,

c - miedź rodzima $\mathrm{Cu}$, gromada pierwiastki rodzime, grupa złota rodzimego,

$\mathrm{d}$ - dioptaz $\mathrm{CuSiO}_{3} \cdot \mathrm{H}_{2} \mathrm{O}$, gromada krzemiany, grupa łowozierytu,

e - atacamit $\mathrm{Cu}_{2} \mathrm{Cl}(\mathrm{OH})_{3}$, gromada halogenki, grupa halitu,

$\mathrm{f}$ - libethenit $\mathrm{Cu}_{2} \mathrm{PO}_{4}(\mathrm{OH})$, gromada fosforany, grupa lazulitu

Fot. A. Tomaszewska-Szewczyk (zbiory własne) 
Większość kwestii z zakresu metalurgii potraktowana jest w traktacie Teofila Prezbitera dość marginalnie. Autor zaczyna od opisu przygotowań rudy do wytopu. Kopaliny układano w stos i wypalano podobnie jak wapno. Według jego słów, w wyniku tego procesu nie zmieniały barwy, ale dawały się potem łatwo pokruszyćc ${ }^{79}$; jednak wbrew temu, co pisze, w czasie takiego prażenia pewna część surowca przechodzi w tlenki miedzi, czemu towarzyszy zmiana barwy na brązową. Drobno pokruszony materiał układano w piecu na przemian z węglem drzewnym i całość wypalano z dostępem powietrza. Miedź należy do nielicznych metali, które można wytopić wprost z rudy. Obecnie ten sposób wykorzystuje się w przerobie siarczków, natomiast ze związków węglanowych otrzymuje się ją metodą ługowania. Autor podaje, że proces wytapiania powtarzano parokrotnie ${ }^{80}$, co może się wiązać z pozyskiwaniem miedzi z rud, które należą do mało miedzionośnych, wymagających wielokrotnego prażenia i przetopu.

W wyniku przetopu otrzymywano miedź zanieczyszczoną ołowiem, nazywaną czarną. Poddawano ją rafinacji, aby uzyskać wyższy stopień czystości; w kolejnym rozdziale można znaleźć opis takiego zabiegu ${ }^{81}$. W tym celu do żelaznego tygla pokrytego na zewnątrz i wewnątrz gliną wkładano miedź i przykrywano ją warstwą drobnego węgla. Za pomocą pracy miechów topiono ją, a następnie odkrywano i posypywano pyłem węglowym mieszając drewnianym patykiem. Ołów w postaci tlenkowej osadzał się na węglu, który usuwano. W ten sposób oczyszczoną miedź nazywano paloną - „cuprum torridum”. Aby sprawdzić jej czystość, wykonywano próbę. Jeszcze gorącą brano w kleszcze i na kowadle uderzano młotem. Gdy się rozkruszała, cały proces powtarzano. Domieszka ołowiu w miedzi powoduje bowiem kruchość tego układu, a jej rafinowanie było stosowane już w epoce brązu ${ }^{82}$.

We fragmencie kończącym rozdział o miedzi znajdujemy opis innej kopaliny - nazywanej przez Teofila „calamina” - i sposób jej przygotowania do dalszej obróbki ${ }^{83}$, a w kolejnych sposób wytapiania stopów mosiężnych ${ }^{84}$. Oczywiście pod tą nazwą kryją się galmany: smithsonit i hemimorfit; ponieważ ich nie rozróżniano, więc do sporządzania stopu używano zapew-

79 Prezbiter, Diversarum, 117.

80 Prezbiter, Diversarum, 117.

81 Prezbiter, Diversarum, 121.

82 Dziekoński, „O zastosowaniu”, 143.

83 Prezbiter, Diversarum, 117.

84 Prezbiter, Diversarum, 118-120. 
ne obu. Kopalinę, podobnie jak rudę miedzi, najpierw układano w formie dużego stosu i prażono do białości. Wystudzoną i rozdrobnioną mieszano z pyłem węglowym. Następnie wkładano do glinianych tygli w ilości szóstej części całego wsadu i dodawano czarną miedź. Ten sposób produkcji pokazano w uproszczeniu na schemacie (rys. 1). Proces wytopu zachodził w piecach $\mathrm{z}$ naturalnym nadmuchem, który został przez autora szeroko omówiony ${ }^{85}$. W momencie stopienia się miedzi zawartość tygla należało mieszać żelaznym prętem. Potem ponownie dodawano wcześniej przygotowaną kopalinę oraz w odpowiednim stosunku miedź i całość przykrywano węglem. Po stopieniu należało jeszcze raz zamieszać, a zawartość wylać w rowki wykopane w ziemi. Otrzymany stop nazywano „aes” i używano między innymi do odlewania kotłów i mis.

Zarówno w czasach powstania traktatu, jak i współcześnie stosowane są dwie metody odlewania. Pierwsza polega na wytopie metalu oraz bezpośrednim odlaniu przedmiotu i z tej według Teofila korzystano przy odlewaniu brązowych dzwonów ${ }^{86}$. Natomiast drugi sposób wymagał sporządzenia najpierw tzw. gąsek, które przetapia się w momencie wykonywania odlewu.

Przez zastąpienie czarnej miedzi rafinowaną („cuprum torridum”) i przetopienie w opisany wcześniej sposób z galmanami otrzymywano stop o nazwie „auricalcum” (rys. 2). Przykładem jego użycia jest sporządzanie kadzielnicy ${ }^{87}$.

Wśród technik wykonywania form odlewniczych autor opisuje żelazne i drewniane formy wielokrotnego wykorzystania, a także odlewanie na wosk tracony, czyli metodę sporządzania wytworów jednostkowych.

Poza odlewaniem metale poddawano również obróbce plastycznej, ale tylko na zimno. Materiałem wyjściowym jest blacha, którą wytwarzano w żelaznych formach. Podczas kształtowania dochodzi do sprasowania krystalicznej struktury, powodującego obniżenie plastyczności materiału, dlatego w miarę potrzeby należy go wyżarzać (glijować), przywracając w ten sposób podatność na dalszą obróbkę. Jedną z opisanych w traktacie technik było repusowanie reliefowe (trybowanie) ${ }^{88}$. Powtarzające się ornamenty wykonywano stalowymi stemplami ${ }^{89}$. W różny sposób opracowywano również po-

85 Prezbiter, Diversarum, 118-119.

86 Prezbiter, Diversarum, 145-154.

87 Prezbiter, Diversarum, 109-116.

88 Prezbiter, Diversarum, 106-109, 126-129, 134-135.

89 Prezbiter, Diversarum, 129-131. 


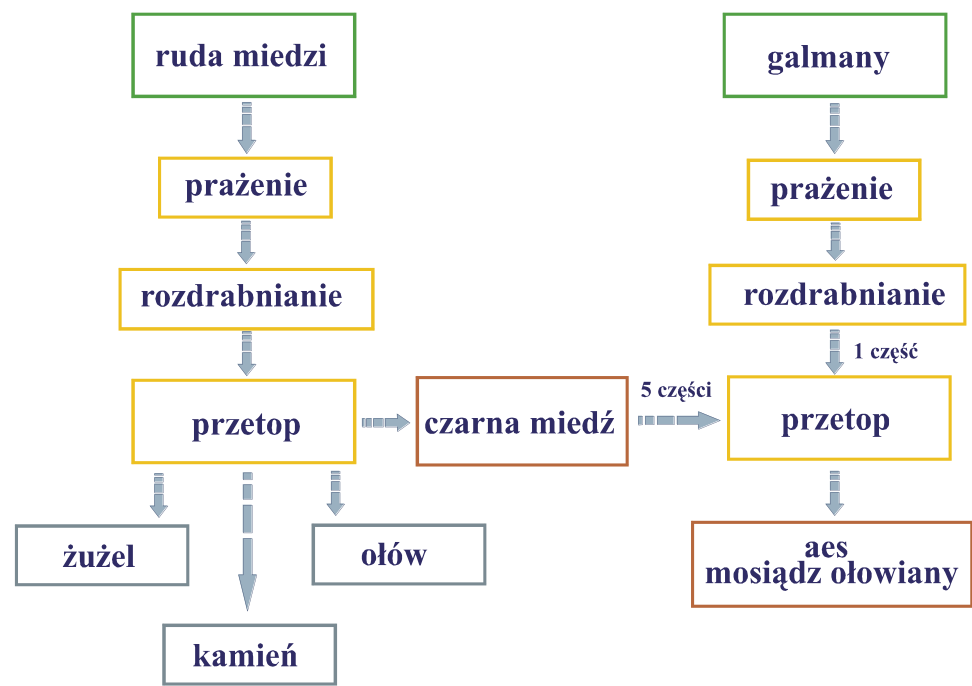

Rys.1. Schemat kolejności zabiegów przy wyrobie mosiądzu ołowianego - aes według traktatu Teofila Prezbitera z początku XII w.

Rys. Alina Tomaszewska-Szewczyk

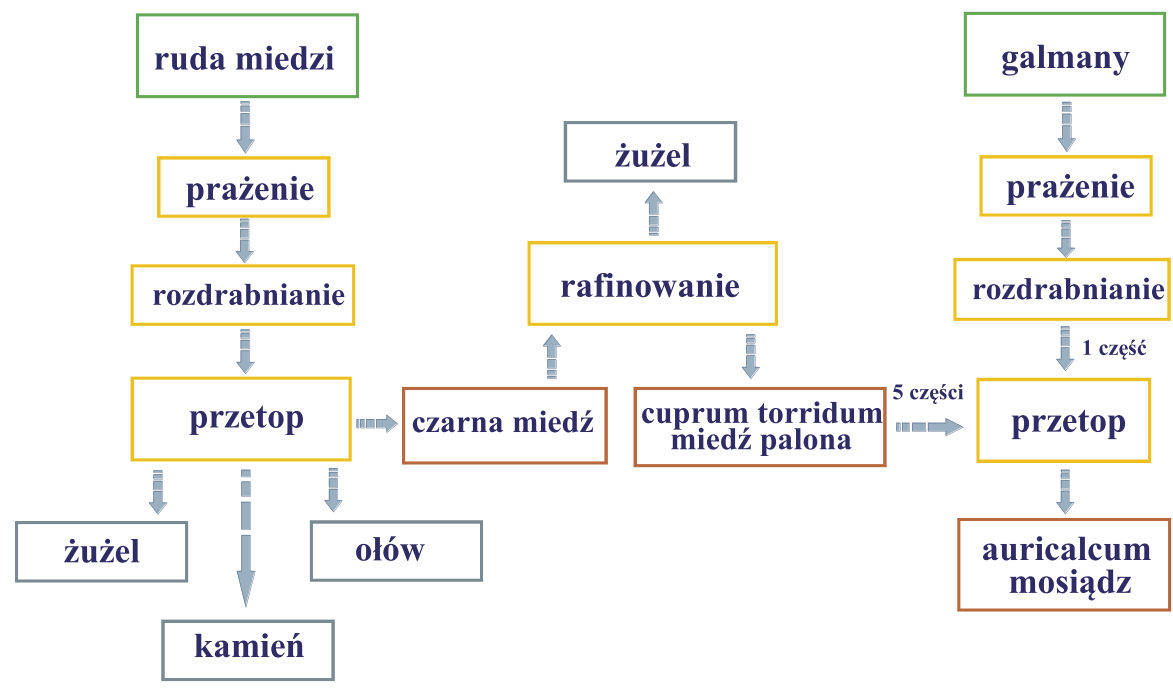

Rys.2. Schemat kolejności zabiegów przy wyrobie mosiądzu - auricalcum według traktatu Teofila Prezbitera z początku XII wieku

Rys. Alina Tomaszewska-Szewczyk 
wierzchnię: cyzelowano, szlifowano i polerowano, fakturowano ${ }^{90} \mathrm{i}$ grawerowano używając rozmaitych rylców ${ }^{91}$, a także zdobiono ażurem ${ }^{92}$. Stosowano również wiele technik specjalnych: złocenie, barwienie ${ }^{93}$, emaliowanie ${ }^{94}$, kameryzowanie $^{95}$, dekorowanie niello ${ }^{96}$ i filigranem ${ }^{97}$. Spośród wymienionych technik opracowywania powierzchni wyrobów wykonanych z obu mosiężnych stopów Mnich Teofil podaje jedynie cyzelowanie, polerowanie i szlifowanie. Mosiądz niezawierający ołowiu mógł być również złocony ogniowo ${ }^{98}$.

Poszczególne części składowe przedmiotów wymagały łączenia, dlatego szerokie zastosowanie znalazło lutowanie. W traktacie znajdujemy szczegółowe opisy wykonania lutów na cynie, srebrze, złocie, żelazie, a także na mosiądzu $^{99}$. Stopy mosiężne lutowano opiłkami srebra i miedzi; taki lut, składający się z dwóch części proszku srebrnego i jednej miedzianego, należy do średnio twardych, czyli o temperaturze topnienia nieco powyżej $500^{\circ} \mathrm{C}$. Jako topnik wykorzystywano kamień winny ${ }^{100}$ (zwyczajowa nazwa wodorowinia$\mathrm{nu}$ potasu $\mathrm{KHC}_{4} \mathrm{H}_{4} \mathrm{O}_{6}$ ), który rozcierano $\mathrm{z}$ dodatkiem soli w wodzie. Użycie tego typu środków ma decydujące znaczenie dla trwałości łączenia, ponieważ chronią one metal przed utlenianiem w czasie gdy poddany jest działaniu wysokiej temperatury, rozpuszczają tlenki wcześniej powstałe na jego powierzchni, obniżają również napięcie powierzchniowe między lutem a łączonym metalem ułatwiając jego wnikanie w szczelinę.

W traktacie zostały opisane różne zastosowania stopów mosiężnych. Z mosiądzu wykonywano ozdobne ćwieki, którymi wybijano pochwy do noży i skórzane okładki ksiąg101, ciągnięto drut służący do inkrustowania żelaznych przedmiotów ${ }^{102}$. Wytwarzano z niego narzędzia rzemieślnicze, na przykład

\footnotetext{
Prezbiter, Diversarum, 126.

Prezbiter, Diversarum, 65.

Prezbiter, Diversarum, 125.

Prezbiter, Diversarum, 124-125.

Prezbiter, Diversarum, 101-103.

Prezbiter, Diversarum, 100-101.

Prezbiter, Diversarum, 76, 77, 79-80, 88.

Prezbiter, Diversarum, 97.

Prezbiter, Diversarum, 122.

Prezbiter, Diversarum, 79.

100 Osad z wina zbierany z dna naczyń.

${ }^{101}$ Prezbiter, Diversarum, 133.

102 Prezbiter, Diversarum, 160.
} 
szczotki do polerowania złoceń ${ }^{103}$. Ponadto ze stopu mosiężnego oczyszczonego z ołowiu („auricalcum”) sporządzano proszki pozłotnicze ${ }^{104}$.

Traktat Teofila Mnicha miał być podręcznikiem dla rzemieślników, dlatego nie znajdujemy w nim wiadomości z zakresu geologii ani techniki górniczej. Wzmianki o metalurgii i wiedza o innych procesach, takich jak odlewanie, stosowanie matryc, wykonywanie złoceń, świadczą o zaawansowaniu i wszechstronności ówczesnego rzemiosła - niektóre opisane metody są stosowane z powodzeniem do dziś. Z technologicznego punktu widzenia interesująca jest umiejętność wytwarzania różnych stopów mosiężnych, których właściwości były dobierane w sposób świadomy, w zależności od ich przeznaczenia. Jednak sposób sporządzania mosiądzu w świetle tego traktatu wydaje się bardziej archaiczny w porównaniu do metod przedstawionych w pismach z czasów rzymskich, ponieważ nie używano do jego wyrobu narostu piecowego, czyli powstałego z galmanów tlenku cynku, a jedynie niepoddaną obróbce kopalinę.

\section{Bibliografia}

\section{Druki i opracowania}

Baines, John, i Jaromir Málek. Wielkie kultury świata. Egipt. Warszawa: Świat Książki, 1996.

Bańkowski, Andrzej. Etymologiczny słownik języka polskiego. T. 2 L-P. Warszawa: PWN, 2000.

Bisht, A. S., i R. C. Jain. "Sixth Century Metal Images from Phophnar - a Scientific Study". Conservation of Cultural Property in India 14-15 (1981-1982): 28-30.

Brepohl, Erhard. Theophilus Presbyter und die mittelalterliche Goldschmiedekunst. Wien-Köln-Graz: Böhlau-Verlag, 1987.

Cameron, H. K. "Technical Aspects of Medieval Monumental Brasses". The Archaeological Journal 131 (1974): 215-237.

Craddock, Paul. "The Composition of the Copper Alloys Used by the Greek, Etruscan and Roman Civilizations. 3. The Origins and Early Use of Brass". Journal of Archaeological Science 5 (March 1978): 1-16. doi:10.1016/0305-4403(78)90015-8. Dostęp 16 marca 2016.

Dowdall, Launcelot D. De mirabilibus auscultationibus. Oxford: Clarendon Press, 1909. https://archive.org/details/demirabilibusaus00arisrich. Dostęp 19 marca 2016.

${ }^{103}$ Prezbiter, Diversarum, 87, 134-135.

104 Prezbiter, Diversarum, 23, 24. 
Dziekoński, Tadeusz. „O zastosowaniu pokładoznawstwa i metaloznawstwa przy badaniu historii technologii miedzi i brązu”. W Studia z dziejów górnictwa i hutnictwa. T. 1, 131-182. Wrocław: Ossolineum, 1957.

Encyclopaedia Britannica. T. 4. Chicago-London-Toronto: University of Chicago, 1969. Encyklopedia sztuki starożytnej. Europa. Azja. Afryka. Ameryka. Warszawa: WAiF; Warszawa: PWN, 1998.

Forbes, Robert J. Studies in Ancient Technology. T. 8. Leiden: Brill, 1972.

Fredouille, Jean-Claude. Słownik cywilizacji rzymskiej. Katowice: Wydawnictwo „Książnica”, 1996.

Hensel-Moszczyńska, Barbara. „Wyroby z miedzi i jej stopów z wczesnośredniowiecznej Kruszwicy”. Slavia Antiqua 28 (1981/1982): 127-221.

Kharakwal, J. S., i L. K. Gurjar. "Zinc and Brass in Archaeological Perspective”. Ancient Asia 1 (2006): 139-159. doi.org/10.5334/aa. Dostęp 14 lutego 2016.

Krawczuk, Aleksander. „Mosiądz i tlenek cynku w starożytności. Wybór źródeł pisanych”. Archeologia 8 (1956) 2: 435-456.

Krawczuk, Aleksander. „Z zagadnień krytyki źródeł do dziejów metalurgii antycznej: mosiądz i cynk w starożytności”. Kwartalnik Historii Kultury Materialnej 5 (1956): 283-287.

Mende, Ursula. Die Bronzetüren des Mittelalters 800-1200. München: Hirmer Verlag, 1994.

Molenda, Danuta. „Górnictwo kruszcowe na terenie złóż śląsko-krakowskich do połowy XVI wieku”. W Studia z dziejów górnictwa i hutnictwa. T. 8, red. Jan Pazdur (Studia i Materiały z Historii Kultury Materialnej, t. 15, red. Aleksander Gieysztor). Wrocław: Ossolineum; Warszawa: PAN, 1963.

Molenda, Danuta. „Górnictwo kruszców”. W Zarys dziejów górnictwa na ziemiach polskich, red. Jan Pazdur. T. 1, 120-162. Katowice: Wydawnictwo Górniczo-Hutnicze, 1960.

Molenda Danuta. „W sprawie badań huty miedzi w Mogile pod Krakowem w XV i XVI wieku”. Przegląd Historyczny 66 (1975) 3: 369-382.

Parafiniuk, Jan. Minerały. Systematyczny katalog 2004. Warszawa: Towarzystwo Geologiczne „Spirifer”, 2005.

Peltzner, Arthur. „Geschichte der Messingindustrie und der künstlerischen Arbeiten in Messing (Dinanderies) in Aachen und den Ländern zwischen Maas und Rhein von der Römerzeit bis zur Gegenwart“. Zeitschrift des Aachener Geschichtsvereins 30 (1908): 235-463.

Piaskowski, Jerzy. „Metalurgia w ‘Historii naturalnej’ G. Pliniusza Starszego”. Archeologia 9 (1957): 99-119.

Piaskowski, Jerzy. Technologia dawnych odlewów artystycznych. Kraków: Wydawnictwo Instytutu Odlewnictwa, 1981. 
Piaskowski, Jerzy. „Technologia metali w XI-XII w. w świetle książki Teofila ‘O sztukach rozmaitych ksiąg troje”". Studia i Materiały z Dziejów Nauki Polskiej 10 (1955) 3: 143-175.

Radwanek-Bąk, Barbara. „Charakterystyka petrograficzna utlenionych rud cynku ze złóż obszarów Bolesławia i Olkusza”. Rocznik Polskiego Towarzystwa Geologicznego 53 (1983) 1-4: 235-254. https://geojournals.pgi.gov.pl/asgp/article/download/12034/10509. Dostęp 19 marca 2016.

Roaf, Michael. Wielkie kultury świata. Mezopotamia. Warszawa: Świat Książki: Diogenes,1998.

Scott, David A. Metallography and Microstructure of Ancient and Historic Metals. Singapore: Oxford University Press, 1991.

Sculpture from Antiquity to the Present Day from the Eighth Century BC to the Twentieth Century, red. Georges Duby i Jean-Luc Daval. Köln: Taschen, 2002.

Sherwood, Andrew N., Milo Nikolic, i John W. Humphrey. Greek and Roman Technology: A Sourcebook: Annotated Translations of Greek and Latin Texts and Documents. London- New York: Routledge, 2003.

Słownik chemiczny. Warszawa: Wiedza Powszechna, 1995.

Smithson, James. "A Chemical Analysis of some Calamines". Philosophical Transactions of the Royal Society of London 93 (1803): 12-28. http://rstl.royalsocietypublishing. org/content/93/12.full.pdf+html. Dostęp 19 marca 2016.

Stahlschmidt, Rainer. „Das Messinggewerbe im Spätmittelalterlichen Nürnberg“. Mitteilungen des Vereins für Geschichte der Stadt Nürnberg 57 (1950): 124-149.

Sun Shuyun, Han Rubin. "A Preliminary Study of Early Chinese Copper and Bronze Artifacts”. Tłumaczenie Julia K. Murray. Early China 9-10 (1983-1985): 268. http:// www.jstor.org/stable/23351611. Dostęp 19 marca 2016.

Teofil Prezbiter. Diversarum artium schedula. Średniowieczny zbiór przepisów o sztukach rozmaitych. Tłumaczenie Stanisław Kobielus. Kraków: Tyniec. Wydawnictwo Benedyktynów, 1998.

The Geography of Strabo. Literally translated, with notes, in three volumes. London: George Bell \& Sons, 1903. http://www.perseus.tufts.edu/hopper/text?doc=Strab.+toc\&redirect=true. Dostęp 19 marca 2016.

Żaba, Jerzy. Ilustrowana encyklopedia skał i minerałów. Katowice: Videograf II, 2010.

\section{Materiały internetowe}

Habashi, Fathi. Discovering the 8th Metal. A History of Zinc. http://www.azmc.co/en/ encyclopedia/discovering-the-8th-metal/. Dostęp 19 marca 2016.

Harris, Reg. The Warmley Works of William Champion. http://www.bittonfamilies.com/ WarmleyBrassWorks.html. Dostęp 14 lutego 2016. 
